\title{
TRÊS VIVAS AO PROLETARIADO! \\ Para uma contextualizaçáo da obra gorziana da década de 1960
}

\author{
Nuno Miguel Cardoso Machado \\ Universidade de Lisboa (Ulisboa), Lisboa, Portugal. E-mail: nuno.cocas.machado@gmail.com \\ DOI: http//dx.doi.org/10.17666/319107/2016
}

\section{Introdução}

Mas a critica será apenas idealista e sem alcance real se não se encarnar em uma luta reivindicatória e politica por parte da classe social dominada e capaz de se tornar

dominante

(Gorz, 1968, p. 17).

André Gorz é sobejamente conhecido no debate sociológico contemporâneo acerca da crise da sociedade do trabalho (Gollain, 2000; Castel, 2013). Gorz atingiu uma grande notoriedade com a publicação do seu livro polêmico Adeus ao proletariado (Gorz, [1980] 1982), no qual critica ferozmente o marxismo tradicional ${ }^{1}$ e a sua "religiaáo do proletariado". Todavia, a vasta obra gorziana publicada nas décadas anteriores nem sempre tem merecido a devida atenção.

Artigo recebido em 15/01/2015

Aprovado em 13/01/2016
Apenas um confronto crítico com esse corpus teórico permitirá analisar comparativamente os diferentes momentos que caracterizam a evolução do pensamento de André Gorz. Essa análise crítica adquire uma importância acrescida, pois revelará que, nos seus primeiros escritos, Gorz defende, em muitos aspectos, teses diametralmente opostas àquelas sustentadas a partir de Adeus ao proletariado, seu livro mais conhecido.

Como se denota no Quadro 1, o pensamento de Gorz é marcado por diversas fases e, consequentemente, por diversas rupturas. Assim, Gorz foi sucessivamente um dos principais autores existencialistas (na década de 1950), um dos grandes impulsionadores da Nova Esquerda francesa (na década de 1960), o fundador da ecologia política (na década de 1970), um dos pioneiros na discussão acerca da crise do trabalho (nas décadas de 1980 e 1990) e, finalmente, um crítico impiedoso da sociedade mercantil (na década de 2000). 
Quadro 1

A evolução do pensamento de André Gorz

\begin{tabular}{|c|c|c|c|}
\hline $\begin{array}{l}\text { Período } \\
\text { Histórico }\end{array}$ & Caraterização Teórica & Obras & Ano \\
\hline $\begin{array}{l}\text { Década } \\
\text { de } 1950\end{array}$ & $\begin{array}{l}\text { Existencialismo: influência de } \\
\text { Sartre }\end{array}$ & $\begin{array}{l}\text { Fundamentos para uma moral } \\
\text { O traidor } \\
\text { A moral da história }\end{array}$ & $\begin{array}{l}1955 \\
1958 \\
1959\end{array}$ \\
\hline $\begin{array}{l}\text { Década } \\
\text { de } 1960\end{array}$ & $\begin{array}{l}\text { Marxismo tradicional/ontologia } \\
\text { do trabalho }\end{array}$ & $\begin{array}{c}\text { Estratégia operária e neocapitalismo } \\
\text { O socialismo difícil } \\
\text { Reforma e revoluçấo }\end{array}$ & $\begin{array}{l}1964 \\
1968 \\
1969\end{array}$ \\
\hline $\begin{array}{l}\text { Década } \\
\text { de } 1970\end{array}$ & $\begin{array}{l}\text { Viragem ecológica: influência de } \\
\text { Illich }\end{array}$ & $\begin{array}{c}\text { Divisáo do trabalho e modo de produçáo capitalista } \\
\text { Crítica do capitalismo quotidiano } \\
\text { Ecologia e politica }\end{array}$ & $\begin{array}{l}1973 \\
1973 \\
1975\end{array}$ \\
\hline $\begin{array}{l}\text { Década } \\
\text { de } 1980\end{array}$ & $\begin{array}{l}\text { Grande ruptura: crítica do } \\
\text { trabalho e do proletariado }\end{array}$ & $\begin{array}{l}\text { Adeus ao proletariado } \\
\text { Os caminhos do paraíso } \\
\text { Metamorfoses do trabalho }\end{array}$ & $\begin{array}{l}1980 \\
1983 \\
1988\end{array}$ \\
\hline $\begin{array}{l}\text { Década } \\
\text { de } 1990\end{array}$ & Reformismo & $\begin{array}{l}\text { Capitalismo, socialismo, ecologia } \\
\text { Misérias do presente, riqueza do possivel }\end{array}$ & $\begin{array}{l}1991 \\
1997\end{array}$ \\
\hline $\begin{array}{l}\text { Década } \\
\text { de } 2000\end{array}$ & $\begin{array}{l}\text { Radicalizaçáo: descoberta da } \\
\text { Nova Crítica do Valor }\end{array}$ & $\begin{array}{l}\text { O imaterial } \\
\text { Ecologica }\end{array}$ & $\begin{array}{l}2005 \\
2008\end{array}$ \\
\hline
\end{tabular}

Fonte: elaborado pelo autor.

Apesar dessa heterogeneidade, excetuando alguns "especialistas" (Bowring, 2000; Little, [1996] 2013; Silva, 2002), a recepção da teoria gorziana tende a ser monolítica ou unidimensional. A literatura secundária ocupa-se, na maior parte dos casos, exclusivamente do pensamento tardio de Gorz, escamoteando pura e simplesmente as obras anteriores a Adeus ao proletariado (Abramovay, 2009; Borot, 2001; Camargo, 2010; Cardoso, 2011; Freitas, 2008; Gomes, 2005; Lane, 2011; Langer, 2003; Mello, 2007; Miguel, 2006; Sobel, 2010, 2011). ${ }^{2}$

Com a exceção de Josué Pereira da Silva (2002) e de Finn Bowring (2000), os autores que abordam a obra gorziana da década de 1960 centram a atenção unicamente em Estratégia operária e neocapitalismo (Rodrigues, 2009), não apresentam qualquer análise comparativa desses escritos com o restante edifício teórico de Gorz (Queiroz, 1999) ou destacam - a meu ver erradamente - uma suposta continuidade entre a obra gorziana na sua totalidade (Gollain, 2000; Granter, 2009; Lodziak e Tatman, 1997). ${ }^{3}$
Durante a década de 1960, Gorz desenvolverá a teoria marxista tradicional exposta pela primeira vez em A moral da história (Gorz, [1959] 1969). Como refere Queiroz (1999, p. 70), "toda a reflexão desenvolvida por Gorz nos anos [...] 60 esteve intimamente vinculada a um objetivo específico: pensar as novas características que o capitalismo assumia e propor novas alternativas de luta à classe trabalhadora”. Em outros termos, Gorz pretende elucidar as pré-condições necessárias para que o proletariado dos países capitalistas ocidentais se torne revolucionário - isto é, adquira a sua "consciência de classe" - e lute pela instauração do socialismo. ${ }^{4}$

Nesse sentido, a seguir são listados os principais objetivos deste artigo:

1. A contextualização social e intelectual da obra gorziana da década de 1960. Gorz assume-se como um dos principais nomes da Nova Esquerda francesa (Hirsh, 1981; Poster, 
1975), que, como é sabido, desempenhou um papel determinante na revolta de Maio de 1968.

2. A discussão detalhada dos escritos gorzianos desse período. Nessa fase, o pensamento do autor é norteado por um conjunto de ideias-chave:

a. o trabalho é entendido de modo positivo. $\mathrm{O}$ principal objetivo (socialista) é libertar o trabalho do jugo imposto pela classe capitalista;

b. a transição para o socialismo é entendida nos moldes do marxismo tradicional enquanto "apropriação coletiva dos meios de produção”. No entanto, Gorz não rejeita medidas intermediárias introduzindo o conceito de "reformas revolucionárias";

c. o proletariado continua a ser entendido, à semelhança de $A$ moral da história, como o sujeito revolucionário;

d. Gorz identifica, contudo, uma série de transformaçóes na composição do proletariado: a "nova classe operária" (Mallet, [1963] 1975), constituída pelos trabalhadores qualificados e "polivalentes" das indústrias de ponta, é potencialmente a nova vanguarda do movimento operário;

e. no seguimento das teses defendidas por Cornelius Castoriadis e pelo operaísmo italiano, a autogestáo é apresentada como uma espécie de panaceia. O controle operário do processo e das condiçóes de trabalho permitirá abolir a alienação inerente à divisão capitalista do trabalho. A alienação do trabalho é, portanto, superável; e,

f. seguindo a tese predominante na Nova Esquerda, Gorz defende que teráo de ser as necessidades qualitativas - nomeadamente a superação da alienação do trabalho e do consumo - a despoletar a consciência revolucionária do proletariado, uma vez que o "neocapitalismo" é capaz de satisfazer a maioria das necessidades de natureza quantitativa e de erradicar a privaçấo material da maior parte dos assalariados.

3. A contextualização desse núcleo conceitual e teórico através da análise comparativa das múltiplas fases que marcam a evolução do pensamento de Gorz.
Este último objetivo, em particular, parece-me suprir uma lacuna fundamental na literatura secundária. A periodização adotada (ver Quadro 1) capta as várias nuances e inflexóes do pensamento de André Gorz. Desse modo, a principal contribuição deste artigo é a proposta de uma grelha de leitura original (ver seção "Análise comparativa do pensamento de André Gorz" e Quadro 2), que permite analisar cronologicamente várias dimensões da teoria gorziana (trabalho, alienaçâo, dominação, sujeito, tecnologia etc.).

\section{Contexto francês}

Segundo Poster, na década de 1960,

[...] tornou-se claro que um novo mundo social estava em processo de formação: empresas enormes, concentrando uma imensa riqueza, dominavam uma economia cada vez menos concorrencial; o Estado desempenhava um papel central na regulação de numerosos aspectos da economia; as empresas começavam a organizar o consumo através dos media, das modas passageiras (style changes) e da obsolescência planificada; os progressos científicos e técnicos superavam os sonhos atrozes dos profetas do progresso: viagens à Lua, reatores nucleares, produtos sintéticos, computadores, conhecimento sobre os processos reprodutivos vitais, [...] crescimento perturbador da poluição. Os ambientes humanos converteram-se em novos subúrbios e novas cidades. A disseminação das atividades de lazer, do cinema, do desporto, do automóvel, transformou as experiências quotidianas mais corriqueiras. Os hábitos sexuais reduziram as práticas puritanas. Nada parecia seguro em face dessas mudanças (Poster, 1975, p. 361). ${ }^{5}$

Brooks (2010, p. 137), por seu turno, salienta que os principais "acontecimentos políticos e mudanças culturais" que marcaram a França durante a década de 1960 foram: "o nascimento da 5a República, o rescaldo da Guerra da Argélia, a ascensão da Nova Esquerda, e a incubação do movimento estudantil". Para além disso, o "reformismo" tinha atingido os seus píncaros "entre as principais orga- 
nizaçóes do movimento operário francês”, em virtude da

[...] prosperidade relativa [...] da classe operária. Durante os anos 60, a França conheceu as maiores taxas de crescimento econômico da era pós-guerra, com uma taxa de crescimento anual [média] do Produto Interno Bruto de 4,9\% (Brooks, 2010, p. 149).

O reformismo político e sindical contrastava, todavia, com a enorme contestação anticapitalista nos meios acadêmicos, estudantis e intelectuais que culminaria na revolta de Maio de 1968.

$\mathrm{Na}$ sequência da invasão soviética da Hungria e do XX Congresso do PCUS - que revelou a natureza brutal da União Soviética -, emergiram três correntes críticas do marxismo ortodoxo no seio da esquerda francesa. Em primeiro lugar, o marxismo existencialista consolidou-se. Após o seu breve flerte com o PCF, Sartre empreenderá uma síntese filosófica do marxismo e do existencialismo com a publicação de Crítica da razão dialética, em 1960. Sartre manteve a sua concepção de uma "irredutibilidade fundamental da liberdade individual" (Hirsh, 1981, p. 28); contudo, a sua teoria sofreu transformaçóes "importantes" ao incorporar a noçâo marxista de que a história e a sociedade limitam essa mesma liberdade (Idem, ibidem).

O marxismo existencialista pode ser definido como:

[...] um marxismo não leninista, que conceitua a sociedade industrial avançada sinalizando uma possível eliminação das suas estruturas alienantes; que observa todas as relaçóes da vida quotidiana, e não apenas as relações de produção, para tornar a sociedade inteligível; que vai buscar no existencialismo o esforço para captar os seres humanos no momento da criação ativa do seu mundo, na sua subjetividade (Poster, 1975, p. ix).

Em segundo lugar, para além do marxismo existencialista, surgiu um grupo "revisionista" liderado por Henri Lefebvre e agrupado em torno da revista Arguments. Esse grupo reafirmava a pertinência da teoria marxista, mas entendia que era necessário rever algumas das suas categorias de análise para fazer face à evolução e às mudanças da "estrutura social e das estruturas de consciência" (Hirsh, 1981, p. 5). A análise macrossocial deveria ser complementada com a análise crítica da "vida quotidiana".

Por fim, em terceiro lugar, surgiu uma corrente "esquerdista" (gauchiste) associada à revista Socialisme ou Barbarie e, em particular, a Cornelius Castoriadis. Essa corrente criticava a natureza burocrática e autoritária dos partidos comunistas tradicionais e dos países do "socialismo real" (Idem, ibidem). Em alternativa, propunha a autogestão generalizada $\mathrm{da}$ sociedade pela classe operária.

Essas três correntes acabaram por convergir, durante a década de 1960, na teoria social da Nova Esquerda francesa. A Nova Esquerda rejeitava o capitalismo, o socialismo reformista e o socialismo real, assim como as teorias que lhes estáo subjacentes. Em síntese, a Nova Esquerda francesa "postulava a possibilidade de uma sociedade igualitária liberta da alienação que caracteriza a sociedade burocrática contemporânea”. Ela foi, portanto, uma resposta às contradiçôes da "sociedade industrial avançada" (Idem, pp. 5 e 6$){ }^{6}$

Segundo Hirsh (1981, p. 140), a revolta de Maio de 1968 deu expressão prática aos anseios da teoria da Nova Esquerda. No cerne do Maio de 1968, esteve a reivindicação de uma vida "autêntica”, isto é, não alienada. É possível discernir aqui, obviamente, as influências do marxismo existencialista. Todavia, os protagonistas da revolta defendiam a autogestão - ou controle operário como forma privilegiada de combater a alienação da sociedade capitalista. Nesse âmbito, é possível vislumbrar a influência da corrente esquerdista, associada ao grupo/revista Socialisme ou Barbarie. Não deve ser minimizado também o papel crucial desempenhado pela Internacional Situacionista (IS), que advogava igualmente a constituição de "conselhos operários" e a autogestão do processo produtivo (Jappe, 2008). A ênfase na alienação da "vida quotidiana" resultou, por seu turno, das análises pioneiras de Henri Lefebvre (que foram igualmente aprofundadas pela IS).

Grande parte do impacto do Maio de 1968 deveu-se ao caráter "radicalmente democrático" da 
revolta e à abolição temporária da clivagem entre estudantes e trabalhadores: "um novo futuro político e cultural parecia [efetivamente] possível em França” (Brooks, 2010, p. 211). A sua fraqueza, contudo, residiu no fato de não ter existido um projeto aglutinador capaz de unificar os vários movimentos sociais (Idem, ibidem). Em síntese, a revolta de Maio de 1968 não produziu nenhuma transformação social significativa; tudo o que os principais sindicatos franceses conseguiram foram algumas "reformas e concessóes modestas do patronato" (Idem, p. 214). O movimento desintegrou-se e deu origem aos novos movimentos sociais da década de 1970 (Idem, ibidem).

\section{Nota biográfica de Gorz}

Desde meados da década de 1940 que Gorz era um sartriano convicto, tendo encontrado nessa filosofia um eco da sua crise existencial e identitária (Gorz, [1993] 1997, p. 117; 1999a, pp. 2-3). Nos seus dois primeiros livros - Fundamentos para uma moral (Gorz, [1955] 1977) e O traidor (Gorz, [1958] 1989b) -, Gorz analisara o conceito-chave de alienação do ponto de vista individual, isto é, da "má-fé" sartriana, sendo patente a influência de $O$ ser e o nada. Por sua vez, em $A$ moral da história, Gorz ([1959] 1969) analisara a alienação do ponto de vista social - do trabalho alienado -, sendo evidente a influência da Crítica da razáo dialética de Sartre. A moral da história marcou a sua adesão definitiva ao marxismo.

Assim, durante a década de 1960, Gorz desempenhou um papel primordial na divulgação do marxismo existencialista, até porque Sartre estava imiscuído em estudos de cariz literário, sendo as suas intervençôes políticas "largamente simbólicas" (Brooks, 2010, p. 50). No entanto, na ótica de Hirsh (1981, p. 143), a obra gorziana desse período extravasa os limites do existencialismo; ela é uma síntese das teorias de Sartre, Lefebvre e Castoriadis: "Gorz sintetizou e sumarizou as conclusóes das críticas existencialista, revisionista e esquerdista do marxismo de um modo claro".

Em 1964, Gorz ([1964] 1975a) publica Estratégia operária e neocapitalismo, que se torna rapidamente uma obra de referência no seio da Nova Esquerda, inclusive no mundo anglo-saxônico após a publicação da tradução inglesa (Bowring, 2000, p. 5):

Os críticos de esquerda (a Nova Esquerda) da esquerda de tipo soviético (a Velha Esquerda) afirmaram a necessidade de desenvolver uma forma diferente de socialismo - um [socialismo] que respeitasse a autonomia e a criatividade humanas. Embora várias visões alternativas de uma sociedade socialista tivessem encontrado alguma expressão entre os teóricos da Nova Esquerda, ninguém formulou meios exequíveis para atingir o socialismo. Gorz preencheu este vazio (Lodziak e Tatman, 1997, pp. 37-38, grifo nosso).

Em Estratégia operária e neocapitalismo, Gorz "afastou[-se] das abstrações presentes em $A$ moral da história em direção a uma abordagem mais pragmática (grounded) da estratégia política socialista e da organização do movimento operário" (Brooks, 2010, p. 138). As análises críticas de Marx e de outros autores tinham como único objetivo "extrair e utilizar conceitos que pudessem ter uma utilidade prática para o movimento operário" (Idem, ibidem). Em outros termos, Gorz adota uma concepção instrumental ou "praticista" de teoria.

Nesse livro, Gorz procurou combinar o tema da autogestão com a teoria da alienação desenvolvida por Sartre em Crítica da razáo dialética (Hirsh, 1981, p. 222). À semelhança de Castoriadis, Gorz encontrou na autogestáo - no controle operário do processo produtivo - a soluçáo para os "dilemas do socialismo" (Idem, ibidem). Gorz apoiou-se igualmente nas variantes da autogestão defendidas por marxistas italianos como Vittorio Foa e Bruno Trentin, que procuravam revitalizar o movimento sindical (Idem, ibidem).

Em 1968, Gorz publica uma coletânea de ensaios intitulada $O$ socialismo difícil, que, no essencial, reafirma as teses centrais de Estratégia operária e neocapitalismo. Este último será reeditado em 1969 - com um longo prefácio (Gorz, [1969] 1975b) e um novo capítulo (Gorz, [1966] 1975c) com o título de Reforma e revolução.

$\mathrm{Na}$ segunda metade da década de 1960, "Gorz emergiu como um pensador radical importante e como um intelectual reconhecido" (Brooks, 2010, 
p. 205). Ademais, Poster (1975, p. 363) realça que o pensamento gorziano "antecipou os acontecimentos de Maio”. Segundo o autor,

Gorz chamou [...] a atenção para importância dos estudantes no capitalismo avançado, para o seu papel na reprodução da força de trabalho e para a função da educação na preparação para um emprego proletário na indústria. Desse modo, foi lançada a base teórica para uma aliança entre os estudantes e os operários que se veio a realizar em 1968 (Poster, 1975, p. 369).

Os escritos de Gorz tiveram, pois, uma "influência substancial" sobre os atores que desencadearam a revolta de Maio de 1968 (Little, [1996] 2013, p. 15). Em particular, Gorz defendia um "socialismo existencialista/humanista que coincidia com a insatisfação" manifestada pelos estudantes e pelos trabalhadores franceses dessa altura (Idem, p. 20). ${ }^{7}$

\section{Necessidades quantitativas versus necessidades qualitativas}

A tese central avançada em Estratégia operária e neocapitalismo é que, nos "países capitalistas avançados", a miséria foi largamente erradicada e já não constitui a "condição da maioria" da população (Gorz, [1964] 1975a, p. 75). Em um contexto de produção e consumo de massas, "a reivindicação em nome das necessidades imediatas [...] não vai desembocar na impugnação [...] da sociedade" capitalista (Idem, p. 76).

Como decerto já se percebeu, Gorz defende uma tese predominante entre a Nova Esquerda durante a década de 1960 (basta pensarmos em Herbert Marcuse ou em Guy Debord e na Internacional Situacionista, para citar alguns dos seus nomes mais ilustres). No período histórico que ficaria conhecido como "Os Trinta Gloriosos", assistiu-se a uma situação de pleno emprego e em que a vitória sobre a escassez parecia ser um dado. Desse modo, estando a sobrevivência (aparentemente) assegurada, restava lutar por uma vida autêntica, não alienada.
Nesse contexto, Gorz faz uma distinção entre necessidades (vitais) e exigências (históricas). As necessidades expressam "fins cuja realização se encontra diretamente associada com a produção e reprodução da vida" (Gorz, [1969] 1975b, p. 15) e possuem um caráter eminentemente quantitativo.

O problema é que as reivindicaçóes de natureza quantitativa - nomeadamente as reivindicaçóes salariais - exprimem cada vez menos o "interesse de classe dos trabalhadores" do que o "interesse de uma camada de consumidores subprivilegiados" (Gorz, [1964] 1975a, p. 107). Dito de outra forma: essas reivindicaçóes póem a classe operária a reboque da "sociedade do consumo" e da sua ideologia. Assim, os trabalhadores não contestam o modelo de sociedade em que vivem, mas somente a "parte de riquezas que ela concede ao consumidor assalariado" (Idem, ibidem).

O movimento operário corre, portanto, o risco, segundo Gorz, de reduzir a "luta de classes" a uma luta contra as "disparidades de rendimentos" e contra a distribuição "injusta" do lucro nacional (Idem, p. 111). Ora, o que está em jogo é um problema eminentemente "político" e qualitativo e não uma "questão económica e quantitativa", a saber: a possibilidade de o movimento operário abolir a organização capitalista da produção e da sociedade e instaurar uma alternativa socialista (Idem, p. 113).

É nesse âmbito que as exigências históricas poderão desempenhar um papel decisivo. Ao contrário das necessidades, as exigências históricas do ser humano são fins que os indivíduos almejam atingir "com vistas ao cumprimento autónomo das respetivas faculdades intelectuais, artísticas, afetivas e criadoras" (Gorz, [1969] 1975b, p. 15, grifo no original). Assim, elas não traduzem "a exigência categórica de viver, mas a exigência [...] de viver melhor, ou de viver 'humanamente" (Gorz, [1964] 1975a, p. 103, grifo no original), algo que é impossível na sociedade capitalista.

O neocapitalismo é perpassado por uma contradição nuclear: ao intensificar as forças produtivas, o capital desenvolve inevitavelmente as faculdades intelectuais e criativas dos indivíduos. Uma vez que "a exigência de soberania" é "inerente a toda a práxis consciente" (Gorz, [1969] 1975b, p. 20, nota 1), há a possibilidade de os indivíduos procurarem afirmar as suas capacidades criativas autonomamente, de reclamarem o estatuto de sujeitos (Idem, p. 17). Em 
outros termos, a experiência limitada de autonomia pode desencadear a reivindicação operária de autonomia ilimitada e de controle do processo produtivo que, em última instância, entram em conflito com a lógica de produção capitalista e com as relações hierárquicas no local de trabalho.

Por conseguinte,

A crítica do modelo de civilização capitalista $[\ldots]$ não se funda $[\ldots]$ nem numa ideia $a$ priori da "natureza humana", nem no subjetivismo impressionista. Funda-se na realidade da práxis histórica, pela qual o homem se revela e torna capaz de soberania na própria atividade da produção social (o trabalho social) (Gorz, [1969] 1975b, pp. 19-20).

Em síntese,

Se o desenvolvimento capitalista tornou o nível de vida operário relativamente mais tolerável sob o ângulo do consumo individual, fez ainda mais insuportável a condição operária sob o ângulo das relações de produção e de trabalho, isto é, da alienação no sentido mais lato, não só de exploração, mas também de opressão e de desumanização (Gorz, [1964] 1975a, p. 114).

Nesse sentido, urge aprofundar a consciencialização dessa intolerabilidade, ligando os motivos imediatos de descontentamento às suas "razóes profundas, inerentes às relaçóes sociais e ao poder económico e político" (Idem, p. 115). É a impossibilidade de os trabalhadores obterem uma melhoria qualitativa do seu nível de vida através de aumentos salariais que confere à reivindicação em nome das exigências históricas um "alcance revolucionário" (Idem, pp. 203-204).

\section{Do trabalho alienado ao trabalho qualificado e politécnico}

Apesar de as necessidades mais prementes dos trabalhadores serem satisfeitas pelo "neocapitalismo", a alienação do trabalho continua a ser insuportável. Ela traduz a contradição formal entre a "essência ativa e potencialmente criadora do trabalho" (Gorz, [1964] 1975a, p. 151) e o seu estatuto passivo de mercadoria sob o capitalismo.

Gorz realça a contradição fundamental entre a finalidade interna do trabalho do ponto de vista do trabalhador - produzir riquezas úteis para os seres humanos e criar, simultaneamente, o homem enquanto "produtor universal" - e a sua finalidade externa, isto é, do ponto de vista do capital, a saber: produzir mais-valia (Idem, ibidem).

O desenvolvimento económico, cultural e social [capitalista] não se encontra orientado para o desenvolvimento prioritário dos homens [...], mas em primeiro lugar para a criação de objetos que é possível vender com o máximo lucro, seja qual for a respetiva utilidade ou inutilidade. As atividades [...] vêm-se limitadas em virtude dos critérios de rendibilidade financeira (Idem, p. 167 , grifo no original).

Em vez de a produção estar colocada a serviço da sociedade, é a sociedade que se encontra a serviço da produção capitalista (Idem, pp. 167168). Gorz adverte, contudo, que "a confiscação das mais-valias consumidas pelos capitalistas não permitiria melhorar sensivelmente a condição das classes populares" (Idem, p. 189), pelo que a crítica não deve ser dirigida principalmente

[...] contra o lucro embolsado pelos capitalistas individuais, contra os rendimentos das grandes famílias e do patronato, de maneira a transformar a sociedade. O que está em causa não são os rendimentos individuais que o lucro capitalista faculta, mas a orientação que $o$ sistema e a lógica do lucro imprimem à economia e à sociedade no seu conjunto; é a política de gestão capitalista do aparelho de produção e a inversão das prioridades reais que provoca no modelo de consumo (Idem, pp. 189-190, grifo no original).

A grande contradição do capitalismo é, pois, aquela que opóe as exigências de rentabilidade do capital às exigências "inerentes à atividade autónoma, criadora”, que é um fim em si mesma, pelos trabalhadores (Idem, p. 220). A transição da "me- 
canização" para a "automação" é responsável pela crise da organização capitalista do trabalho e das técnicas de dominação a ela associadas (Idem, p. 252). Essa crise traduz a impossibilidade de avaliar com critérios quantitativos um desenvolvimento econômico e social que tende a tornar-se crescentemente qualitativo:

[O] trabalho [...] deixa de poder avaliar-se economicamente, pelo fato de já não ser uma quantidade de tempo e de energia, mercadoria indiferenciada, mas práxis consciente, nos trabalhadores qualificados, da sua autonomia, acarretando em si, enquanto atividade de criação e iniciativa, as próprias exigências soberanas. [...] [O]s trabalhadores qualificados já não são, e sê-lo-ão cada vez menos, portadores de energia física intercambiáveis (Idem, p. 231, grifos no original).

À semelhança de Serge Mallet ([1963] 1975), Gorz vislumbra na "nova classe operária" o agente privilegiado para a abolição da alienação:

[O]s trabalhadores qualificados das indústrias de ponta, minoritárias hoje, maioritárias amanhã, possuem como coisa própria, diferentemente dos proletários clássicos, a força de trabalho que eles ministram: possuem-na como coisa própria porque foram eles próprios a adquiri-la; porque são os que se encontram em melhor situação para conhecer o seu modo de emprego; porque semelhante força, longe de dever ou de poder combinar-se na exterioridade com outras forças, impõe-se já, no ponto de partida, pela própria capacidade para organizar as suas relações com as forças dos outros. É impossível dominar o trabalhador qualificado das indústrias de ponta; [ele] revela-se ao mesmo tempo como força de trabalho e como aquele que a ordena, em suma, é uma práxis-sujeito cooperando com outras práxis para uma tarefa comum [...]. O trabalhador surge agora como parte integrante da sua força de trabalho, e é já impossível quantificar a última dissociando-a do primeiro, uma vez que ambos constituem a mesma autonomia humana (Gorz, [1964] 1975a, pp. 231-232, grifos no original).
O trabalho qualificado passa a ser entendido, antes de tudo, como a produção de uma coisa predeterminada pelos próprios trabalhadores e, para além disso, como a "produção de uma relação dos trabalhadores entre si", isto é, da sua sociabilidade (Idem, p. 238). Ademais, "esbate-se a fronteira entre atividade produtiva e lazer; o trabalho manual e o intelectual tendem a equiparar-se" (Idem, p. 252).

Assim, os trabalhadores "científicos e técnicos, [...] soberanos na sua práxis", encontram-se numa relação de subordinação hierárquica completamente anacrônica diante dos detentores do capital (Idem, p. 232):

A alienação no seio do trabalho tende a desaparecer - uma vez que as equipas de trabalhadores culturais e científicos são os únicos senhores dentro do seu trabalho -, mas a alienação do trabalho subsiste e tende a tornar-se insuportável, em virtude dos limites e da orientação final que a preocupação de rendibilidade financeira [...] impóe à práxis soberana (Idem, p. 233, grifos no original).

É de realçar que, ao contrário do que sucederá a partir de Adeus ao proletariado (ver seção "Análise comparativa do pensamento de André Gorz"), Gorz não propóe a abolição do trabalho, mas a sua transformação (mormente, numa sociedade socialista) em "trabalho qualificado" ou "politécnico". O exercício da autonomia e da criatividade dos seres humanos é equiparado ontologicamente à sua faceta de trabalhadores.

De acordo com o autor, a alienação no exercício do trabalho tende a desaparecer, dado que o "trabalho qualificado" é por definição uma atividade autônoma. Desse modo, apenas subsiste uma alienação "exterior" - fadada a desaparecer - corporizada na subordinação do processo de trabalho às finalidades estranhas que lhe são impostas pelo capital. A revolta dos trabalhadores resultará desta contradição insolúvel entre as suas exigências de autonomia no trabalho e as exigências estranhas do capital. ${ }^{8}$ 


\section{A especializaçáo como mecanismo de dominaçáo da classe capitalista}

Segundo Gorz, é falacioso afirmar que a tecnologia atual (e futura) exige a especialização dos indivíduos (Idem, 1975a [1964], p. 227). Pelo contrário, a produção moderna requer trabalhadores "com uma visão sintética do ciclo produtivo" na sua totalidade (Idem, p. 243), tal como o desenvolvimento das capacidades humanas (Gorz, 1968, p. 60). Assim, a especialização não responde a uma exigência técnica, mas a uma exigência política: ela é promovida deliberadamente pela classe capitalista com o intuito de impedir o desenvolvimento das capacidades autônomas do proletariado, que os conduziria a questionar a divisão das tarefas e a distribuição dos poderes sociais (Idem, ibidem).

Todavia, essa estratégia da classe capitalista está fadada ao insucesso, pois o progresso técnico impõe "objetivamente" uma "formação metodológica e teórica sólida, polivalente, e uma educação para a autonomia” (Idem, p. 62). A tecnologia moderna requer

[...] uma formação de base polivalente, que consiste não na aquisição de um saber particularizado, predigerido e especializado, mas na iniciação [...] aos métodos de pesquisa e de invenção científico-técnicos. Ela exige não que se dê a um aluno um saber e receitas de utilidade imediata, e sim que se lhe ensine em primeiro lugar a aprender, a procurar, a desenvolver seus conhecimentos de maneira autónoma, a dominar conceptual e sinteticamente todo um setor de atividade e de conhecimento em suas articulações com setores conexos (Idem, p. 62, grifo no original).

Nesse sentido, a especialização é o cerne da contradição entre a autonomia crescente - real ou potencial - do trabalho e o seu estatuto subalterno dentro da empresa e da sociedade capitalistas, onde predominam as relaçóes de dominação hierárquicas (Idem, p. 50). Ora, na ótica do autor, é simplesmente impossível pretender impor limites à "necessidade de autonomia". Os trabalhadores tomarão inevitavelmente consciência da "mutilação que lhes é imposta" pelo trabalho capitalista, pois o aumento do conhecimento e das suas competências não é passível de ser aprisionado pela especialização. A "autonomia inerente à práxis cognoscitiva em limites preestabelecidos" acabará por se voltar contra a especialização e contra "o caráter arbitrário desses limites" ao seu livre florescimento (Idem, p. 64). ${ }^{9}$

No neocapitalismo, o trabalho individual e a qualificação associada ao mesmo são encaminhados para uma função e uma qualificação "imediatamente sociais". O indivíduo já não obtém as suas competências através de "trocas com a natureza inorgânica [...] e sim da colaboração social com os demais" (Idem, p. 66). Por conseguinte,

[...] a força de trabalho está em conjunto socialmente qualificada; a relação não é mais a relação isolada do intermediário portador do instrumento com a matéria a ser trabalhada, e sim a relação com o processo industrial que resulta de uma combinação consciente de atividades humanas. A produção não requer mais a combinação exterior, feita por meio de um terceiro, das forças de trabalho que os operários trarão como quantidade de energia fisiológica bruta; requer cada vez mais a combinação recíproca das atividades pelos próprios elementos que a realizam, isto é, a cooperação dentro de equipes em que as barreiras tradicionais entre operários, técnicos e engenheiros são rompidas (Idem, pp. 66-67, grifos no original).

A "base natural" da hierarquia industrial é, portanto, abolida e o sistema tradicional de classificação e de remuneração, fundado na quantidade de trabalho, no rendimento e na qualificação individuais "entra em crise" (Idem, p. 67). Em um conjunto de indústrias-chave, a natureza do trabalho quer em virtude do seu caráter imediatamente social, quer em virtude do seu caráter criativo e autônomo - tende, pois, a entrar em conflito com os critérios de gestão capitalistas (Idem, p. 68). "Um novo agrupamento e uma recomposição das tarefas, [...] uma autogestão pelos trabalhadores do processo de produção [...], tanto em suas modali- 
dades como em suas finalidades" passa a ser sentida como uma possibilidade bastante real, revelando que "a alienação e a mutilação do trabalhador não são [...] consequência natural das técnicas postas em execução" (Idem, ibidem).

É de salientar que, contrariamente à posição que Gorz assumirá nas décadas de 1970 e 1980 (ver seção "Análise comparativa do pensamento de André Gorz"), a especialização do trabalho não é vista como um fator inerente à produção industrial tout court. Para o Gorz dos anos de 1960, a produção moderna exige uma formação multifacetada dos trabalhadores.

Assim, a divisão extrema do trabalho é o resultado de uma decisão política consciente da classe capitalista, uma vez que a elevação do nível de competências e de autonomia dos trabalhadores conduziria a uma radicalização dos mesmos, que colocariam em causa as suas condiçóes de trabalho e o sistema capitalista em geral.

\section{Tempo de trabalho e tempo livre}

Diz-nos Gorz que, no âmbito de uma perspectiva marxista,

[...] é impossível afirmar que o trabalho criador esteja condenado pela evolução das técnicas industriais; que o trabalho produtivo deve, consequentemente, ser considerado como um mau momento a ser passado na vida do indivíduo; e que seu pleno desenvolvimento deve ser buscado permitindo-lhe "desinvestir-se" do trabalho para "investir-se" inteiramente em suas atividades de lazer. Essa tese só seria defensável se o desenvolvimento das forças produtivas permitisse que a atividade do tempo livre fosse considerada como a atividade social principal e o trabalho diretamente produtivo como atividade acessória (acessória tanto por sua pouca duração quanto com relação à potência dos processos automáticos), isto é, como um dado marginal do trabalho social pessoal. A parte essencial da comunicação, as trocas materiais e verbais se processariam então fora da esfera da produção material, com base em uma abundância geral de riquezas sociais; a integração do indivíduo na sociedade e a reapropriação permanente da mesma teriam lugar no reajuste constante do campo social (principalmente cultural), pela livre associação e colaboração voluntária de indivíduos cujo principal objetivo social (consagrado pelas normas culturais da sociedade) seria o desenvolvimento das relações e do intercâmbio intelectual, afetivo, estético, político etc. As relações económicas, de trabalho e de produção, deixariam de ser então dominantes e determinantes das relações sociais; o reino da necessidade cederia diante do reino da liberdade (Idem, pp. 135-136, grifos no original).

\section{Gorz acrescenta que}

Essa perspectiva, porém, está longe de ser real, mesmo que um dia possa vir a sê-lo. E enquanto ela não for atual, as relaçóes económicas continuarão a ser determinadas pelas relaçóes de trabalho $e$ de produção. A produção social continuará a se basear principalmente no trabalho humano; o trabalho social de produção continuará sendo a principal atividade do indivíduo; e é por seu trabalho, principalmente, que este se integrará na sociedade e a ela pertencerá. É para e por um certo tipo de trabalho produtivo que ele será formado (Idem, pp. 136, grifos no original).

Gorz defende aqui uma posição inversa àquela que assumirá no início da década de 1980, quando se dá a grande ruptura no seu pensamento. Se, a partir de Adeus ao proletariado, o trabalho passa a ser visto como uma atividade irremediavelmente heterônoma e alienante, pelo que só resta aos seres humanos reduzir o tempo de trabalho a um mínimo e procurar o pleno desenvolvimento das suas capacidades fora do trabalho (ver seção "Análise comparativa do pensamento de André Gorz"), no final da década de 1960 Gorz ainda acredita em uma possível liberdade no trabalho. Por outras palavras, o trabalho ainda é encarado como a atividade nuclear na vida dos indivíduos, devendo por isso ser enriquecido e libertado.

A distinção entre "tempo livre" e "tempo de trabalho" deve ser abolida em benefício do 
segundo: a instauração de uma "cultura proletária" fará do tempo livre "um prolongamento, uma saída, um campo de aplicação particular da atividade social principal: o trabalho" (Idem, pp. 137-138). Se, na década de 1980, Gorz defenderá uma "política do tempo" consubstanciada em uma reduçấo faseada dos horários de trabalho, atualmente defende que uma sociedade que introduzisse uma semana de trabalho de 32 , ou mesmo de 24 horas, sem que as relaçóes de produção se alterassem, "em nada teria avançado no sentido de uma forma superior de civilização" (Idem, p. 137). Gorz conclui que "não pode haver emancipação do indivíduo social em seu tempo livre se não houver emancipação em sua principal atividade social: o trabalho" (Idem, p. 138). O autor acrescentará alguns anos mais tarde que o trabalho não se tornou supérfluo, pois, "em última análise, continua a ser a fonte de todas as riquezas; após a revolução comunista trabalharemos mais e não menos" (Gorz, [1973] 1976b, p. 92, grifos nossos).

\section{O consumo alienado como contrapartida do trabalho alienado}

Gorz salienta que o capitalismo se esforça por oferecer aos indivíduos meios para se evadirem em relação à "realidade social insuportável" do trabalho alienado (Gorz, [1964] 1975a, p. 168). A homogeneização e a estereotipagem do consumo individual produzem um "indivíduo social [...] a quem a própria socialidade aparece como acidental e estranha: o indivíduo de massa" (Idem, ibidem).

Enquanto consumidor, o indivíduo é solicitado a escapar da sua condição de produtor social alienado e a "reconstituir um microcosmo privado", no qual reina como "soberano solitário" (Idem, p. 169, grifo no original). Dessa maneira, a ideologia associada ao "modelo de consumo 'opulento" não é sobretudo a do "conforto", mas a da "mónada emparedada no seu universo solitário e suficiente" (Idem, ibidem).

A (pseudo)civilização do consumo e do lazer é o antídoto para a incivilidade das relações sociais, das relaçóes de produção e do trabalho. Uma vez alienados no trabalho, é mais fácil alienar os seres humanos no consumo e vice-versa (Idem, p. 175).

O consumidor massificado e passivo, que a produção capitalista exige para conseguir subordinar o consumo, não surge de repente, como muitas vezes se afirma, por meio da publicidade, da moda e das "relaçôes humanas"; pelo contrário, a produção capitalista já o engendrou ao nível das relações de produção e das relações de trabalho, separando o produtor do respetivo produto [...]. Devido ao fato de o trabalhador não se sentir "em casa" no "seu" trabalho, porque o trabalho, negado como atividade criadora, constitui uma calamidade, puro meio para satisfazer as necessidades, o indivíduo [...] só encontra a própria soberania no não trabalho, quer dizer, na satisfação de necessidades passivas, no consumo e na vida doméstica. É com base neste primeiro precondicionamento que o capitalismo consegue [propor aos indivíduos] modos [...] sofisticados [...] de evasão, vender os meios de esquecer, de se distrair das pressões da organização industrial, meios para se sonhar como humano - já que não se trata de o ser (Idem, pp. 168, 174-175, grifos no original).

Gorz conclui que é impossível sair desse "círculo infernal" restringindo as reivindicações ao aumento quantitativo do consumo individual de mercadorias e, inversamente, é impossível contestar eficazmente o modelo de consumo capitalista sem atacar a raiz da "pobreza espiritual": a alienaçáo do trabalho (Idem, p. 176).

Dessa forma, é preciso constituir um verdadeiro "poder operário" ao nível das empresas, que seja capaz de opor-se ao modelo de consumo e de produção vigente, uma ordem de prioridades "baseada em necessidades sentidas" (Idem, pp. 177178). Apenas através da reunificação de produtor e consumidor, "desunidos pelo capitalismo", será possível desenvolver um modelo social, de consumo e de vida alternativo, "a cuja luz o modelo do capitalismo $[\ldots]$ se denunciará na sua absurdidade" (Idem, p. 178). 


\section{As "reformas revolucionárias" e o papel do partido operário}

Ao contrário do que sucederá a partir de Adeus ao proletariado, em que qualificará inequivocamente a dominação vigente nas sociedades capitalistas de "impessoal" (ver seção "Análise comparativa do pensamento de André Gorz"), durante a década de 1960 a teoria gorziana é no mínimo ambígua a esse respeito. Por conseguinte, o autor identifica uma crise da "democracia representativa" ligada à "centralização de fato do poder de decisão nas mãos de uma oligarquia, geralmente ligada aos grupos económicos dominantes" (Gorz, 1968, pp. 13-14). Em outros termos, nos países capitalistas avançados, o "processo de concentração económica, técnica e financeira colocou em mãos de um número restrito de grupos capitalistas decisóes que são determinantes para toda a sociedade" (Idem, p. 14). Assim, na perspectiva de Gorz, é uma dominação de classe que caracteriza, em última instância, a sociedade capitalista.

Consequentemente, o paradigma da luta de classes continua a ser reafirmado pelo autor até ao final da década de 1960: no seu entendimento, a crítica do capitalismo apenas adquirirá um "alcance revolucionário" e uma "verdade histórica" se for o resultado da "ação dos homens $[\ldots]$ enquanto classe" contra o poder do capital (Gorz, [1969] 1975b, pp. 10-11). Apenas os trabalhadores, "enquanto indivíduos de classe", podem contestar eficazmente o capitalismo; a crítica teórica extrai a sua verdade da "práxis histórica do proletariado" (Idem, p. 11).

Não obstante, na ótica de Gorz, a ação da classe operária nos países capitalistas ocidentais já não pode ser apreendida em termos do binômio reforma versus revoluçáo. Essa problemática deve ser reformulada como a possibilidade de implementar reformas revolucionárias, ou seja, "reformas que vão no sentido da radical transformação da sociedade" (Gorz, [1964] 1975a, p. 80).

Gorz parte do pressuposto que nem todas as lutas por reformas são forçosamente "reformistas" (Idem, ibidem). Na sua acepçâo, "é reformista a reforma que subordina os [seus] objetivos aos cri- térios de racionalidade" capitalistas (Idem, p. 81). Em contrapartida, as "reformas anticapitalistas" rejeitam explicitamente esses critérios: elas são reivindicadas "não em função do que é possível [...] mas do que deve tornar-se possivel em função das necessidades e das exigências humanas" (Idem, ibidem, grifo no original). As transformaçóes almejadas supóem que os trabalhadores possam influenciar os processos de tomada de decisão (Idem, p. 82) através do "nascimento de novos centros de poder democráticos" (Idem, p. 82 , nota 1 ).

Por conseguinte, o que distingue, na prática, os dois tipos de reformas não é tanto a natureza de cada uma das reformas per se, tomada isoladamente, quanto

[...] $1^{\circ}$ a presença ou ausência de laços orgânicos entre as diversas reformas; $2^{\circ}$ a cadência e as modalidades da sua efetuação; $3^{\circ}$ a vontade ou a ausência de vontade de aproveitar para novas ações de rotura o abalo do equilíbrio provocado pelas primeiras ações reformadoras" (Gorz, [1966] 1975c, p. 273, grifo no original).

As reformas revolucionárias devem facilitar o estabelecimento do poder autônomo dos trabalhadores - nas empresas, nas municipalidades, nos serviços públicos, nos organismos regionais etc. -, assegurando desse modo a "progressão dialética da luta em nível cada vez mais elevado" (Gorz, [1964] 1975a, pp. 85-86). O derradeiro objetivo desse processo será a "autogestão" (Idem, p. 85) da sociedade pela classe operária.

Segundo Gorz, as reformas revolucionárias desempenham um papel crucial na "formação e educação das massas", facultando-lhes a compreensão prática do socialismo, "não como além transcendente e como futuro indeterminado, mas como o horizonte de uma práxis atuante". O socialismo deixa de ser um objetivo abstrato e passa a ser visado através de objetivos parciais, concretos (Idem, p. 86), que estáo, contudo, "engrenados em necessidades profundas" e que colocam em questão as "estruturas capitalistas" (Idem, p. 87). Em síntese, as reformas devem ser concebidas como meios, e não como objetivos finais, 
"como fases dinâmicas de um processo de lutas" (Gorz, [1966] 1975c, p. 282).

Resta-nos analisar a maneira como Gorz teoriza a tensão entre a ação espontânea do proletariado e a necessidade de organização institucional. Gorz preconiza que o socialismo "só pode ser a hegemonia da classe operária e a propriedade pública dos meios de produção", "o fim da exploração" (Gorz, [1964] 1975a, pp. 87-88, 89). Nessa concepção, o partido (comunista) assume uma importância fundamental. "O Partido [...] deve compreender-se como um mal necessário" (Gorz, [1966] 1975c, p. 320), pois na sua ausência o movimento operário permanece inconsequente:

[...] sem movimento revolucionário, não há partido revolucionário; sem partido revolucionário, não existe movimento revolucionário duradoiro. Foi o que, mais uma vez, confirmou o movimento do Maio Francês [de 1968] (Gorz, [1969] 1975b, p. 32).

Gorz apressa-se a acrescentar, contudo, que a tarefa principal do partido comunista "não é dirigir e controlar a partir de cima, mas estimular e despertar a capacidade de iniciativa, de invenção e de auto-organização das próprias massas" (Gorz, 1975 c [1966], p. 320, grifo no original). De acordo com o autor, o "verdadeiro partido revolucionário” distinguir-se-á pelo fato de, após ter desencadeado o movimento das massas proletárias, se mostrar capaz de se fundir no mesmo e favorecer o nascimento de "assembleias soberanas", aceitando, portanto, a liquidação de toda a estrutura hierárquica, de toda a separação entre dirigentes e dirigidos. "A palavra de ordem da revolução não é 'todo o poder para o Partido', mas 'todo o poder para os sovietes', quer dizer, para as assembleias de produtores soberanos" (Idem, p. 321).

Todavia, não deixa de subsistir uma ambiguidade na posição assumida por Gorz: apesar de apresentar, por vezes, uma linguagem de cariz mais libertário, coexiste no autor um leninismo tradicional mesclado com certa dose de conselhismo (Gorz, [1969] 1975b, pp. 55-72). Até porque, segundo Gorz, é preciso que o Estado se converta no "senhor dos centros realmente motores da economia" (Gorz, [1964] 1975a, p. 163), ou seja, o socialismo é equiparado, de fato, a uma economia de direção central. A planificação estatal deve ser complementada - ratificada? - pela ação dos conselhos operários e dos sindicatos (Idem, pp. 87ss).

Terminaremos esta seção com duas observações. Em primeiro lugar, apesar de transcendê-lo em alguns aspectos (ver início da seção "Do trabalho alienado ao trabalho qualificado e politécnico"), Gorz continua enredado nas aporias do marxismo tradicional: a "contradição fundamental" do capitalismo é aquela entre capital e trabalho (Idem, p. 118); o socialismo é concebido como a "hegemonia da classe operária e a propriedade pública dos meios de produção" (Idem, pp. 87-88) e como o "fim da exploração" (Idem, p. 89).

Em segundo lugar, a "planificação socialista" é entendida como uma planificação das categorias capitalistas (trabalho, dinheiro etc.), assumidas como não problemáticas: os meios ao dispor da mesma são "essencialmente fiscais" (Idem, p. 95). Por conseguinte, apesar de algumas intuições ou afirmações isoladas em sentido contrário, o "socialismo" proposto pelo autor é, no fundo, uma administraçáo "democrática" - ou "autogestão" das categorias capitalistas para colocar um fim à exploração e à alienação do trabalho, que deve ser libertado do jugo da classe dominante. É ainda de ressalvar que essa concepção de planificação - entregue ao Estado - contém implicitamente o perigo de uma deriva autoritária (que foi uma realidade em todos os países do socialismo real).

\section{Análise comparativa do pensamento de André Gorz}

Estamos agora em condiçóes de aferir a posição ocupada pela obra gorziana da década de 1960 no seio do pensamento do autor através de uma análise comparativa. As principais dimensôes da teoria de André Gorz estâo descritas no Quadro 2, que passarei agora a descrever sinteticamente. 
Quadro 2

Dimensões da teoria de André Gorz

\begin{tabular}{|c|c|c|c|c|c|c|c|}
\hline $\begin{array}{l}\text { Período } \\
\text { Histórico }\end{array}$ & $\begin{array}{l}\text { Conceito } \\
\text { de Trabalho }\end{array}$ & $\begin{array}{l}\text { Conceito de } \\
\text { Alienação }\end{array}$ & $\begin{array}{l}\text { Conceito de } \\
\text { Dominação }\end{array}$ & $\begin{array}{l}\text { Sujeito Revo- } \\
\text { lucionário }\end{array}$ & $\begin{array}{l}\text { Rendimento } \\
\text { Básico }\end{array}$ & $\begin{array}{l}\text { Conceito de } \\
\text { Tecnologia }\end{array}$ & $\begin{array}{c}\text { Visão de Socie- } \\
\text { dade Pós-Capi- } \\
\text { talista }\end{array}$ \\
\hline $\begin{array}{c}1946 / \\
1958\end{array}$ & $\begin{array}{l}\text { Positivo } \\
\text { (implícito) }\end{array}$ & $\begin{array}{l}\text { Individual/ } \\
\text { Superável } \\
\text { (psicanálise } \\
\text { existencial) }\end{array}$ & "Má-fé" & $\begin{array}{l}\text { Proletariado } \\
\text { (implícito) }\end{array}$ & $\begin{array}{c}\text { Não } \\
\text { abordado }\end{array}$ & $\begin{array}{l}\text { Positivo } \\
\text { (implícito) }\end{array}$ & $\begin{array}{c}\text { "Moralização da } \\
\text { existência" }\end{array}$ \\
\hline 1959 & $\begin{array}{c}\text { Positivo } \\
\text { (ontológico) }\end{array}$ & $\begin{array}{c}\text { Social/ } \\
\text { Superável } \\
\text { (libertação } \\
\text { no trabalho) }\end{array}$ & $\begin{array}{c}\text { Dominação } \\
\text { direta/de } \\
\text { classe }\end{array}$ & Proletariado & $\begin{array}{c}\text { Não } \\
\text { abordado }\end{array}$ & $\begin{array}{c}\text { Positivo } \\
\text { (apropriação } \\
\text { coletiva dos meios } \\
\text { de produçáo) }\end{array}$ & $\begin{array}{l}\text { Socialismo de } \\
\text { Estado }\end{array}$ \\
\hline $\begin{array}{l}\text { Década } \\
\text { de } 1960\end{array}$ & $\begin{array}{c}\text { Positivo } \\
\text { (ontológico) }\end{array}$ & $\begin{array}{c}\text { Social } \\
\text { (trabalho } \\
\text { alienado) } \\
\text { Superável } \\
\text { (libertação } \\
\text { no trabalho) }\end{array}$ & $\begin{array}{c}\text { Dominação } \\
\text { direta/de } \\
\text { classe }\end{array}$ & $\begin{array}{l}\text { Proletariado } \\
\text { (“Nova Classe } \\
\text { Operária”) }\end{array}$ & $\begin{array}{c}\text { Não } \\
\text { abordado }\end{array}$ & $\begin{array}{l}\text { Positivo } \\
\text { (apropriação } \\
\text { coletiva dos } \\
\text { meios de } \\
\text { produção) }\end{array}$ & $\begin{array}{c}\text { Socialismo } \\
\text { de Estado } \\
\text { (planificação) } \\
\text { + Conselhos } \\
\text { operários } \\
\text { (autogestão) }\end{array}$ \\
\hline $\begin{array}{l}\text { Década } \\
\text { de } 1970\end{array}$ & $\begin{array}{c}\text { Positivo } \\
\text { (ontológico) }\end{array}$ & $\begin{array}{c}\text { Social } \\
\text { (trabalho } \\
\text { alienado) } \\
\text { Superável } \\
\text { (libertação } \\
\text { no trabalho) }\end{array}$ & $\begin{array}{l}\text { Ambivalên- } \\
\text { cia }\end{array}$ & Proletariado & $\begin{array}{c}\text { Não } \\
\text { abordado }\end{array}$ & $\begin{array}{l}\text { Negativo } \\
\text { (civilização } \\
\text { industrial } \\
\quad v s . \\
\text { ferramentas } \\
\text { conviviais) }\end{array}$ & $\begin{array}{c}\text { Produção } \\
\text { microssocial } \\
\text { (ecologicamente } \\
\text { sustentável) } \\
\text { + Alocação } \\
\text { central }\end{array}$ \\
\hline $\begin{array}{l}\text { Década } \\
\text { de } 1980\end{array}$ & $\begin{array}{l}\text { Negativo } \\
\text { (historica- } \\
\text { mente } \\
\text { específico) }\end{array}$ & $\begin{array}{c}\text { Social } \\
\text { (trabalho } \\
\text { alienado) } \\
\text { Insuperável } \\
\text { (reduçáo do } \\
\text { horário } \\
\text { de trabalho) }\end{array}$ & $\begin{array}{c}\text { Impessoal } \\
\text { (insuperável } \\
\text { na esfera } \\
\text { heterônoma) }\end{array}$ & $\begin{array}{l}\text { "Não classe } \\
\text { dos não traba- } \\
\text { lhadores" } \\
\text { Inexistência } \\
\text { (Metamorfoses } \\
\text { do trabalho) }\end{array}$ & Condicional & $\begin{array}{c}\text { Ambivalente } \\
\text { produçáo industrial } \leftrightarrow \\
\text { centralizaçáo }+ \\
\text { lógica capitalista }\end{array}$ & $\begin{array}{c}\text { Sociedade } \\
\text { dual } \\
\text { Esfera da } \\
\text { heteronomia } \\
\text { (mercantil) } \\
\text { Esfera da } \\
\text { autonomia } \\
\text { (não mercantil) }\end{array}$ \\
\hline $\begin{array}{l}\text { Década } \\
\text { de } 1990\end{array}$ & $\begin{array}{l}\text { Negativo } \\
\text { (historica- } \\
\text { mente } \\
\text { específico) }\end{array}$ & $\begin{array}{c}\text { Social } \\
\text { (trabalho } \\
\text { alienado) } \\
\text { Insuperável } \\
\text { (redução do } \\
\text { horário } \\
\text { de trabalho) }\end{array}$ & $\begin{array}{c}\text { Impessoal } \\
\text { (insuperável } \\
\text { na esfera } \\
\text { heterônoma) }\end{array}$ & Inexistência & $\begin{array}{l}\text { Condicional } \\
\text { Incondicional } \\
\text { (Misérias do } \\
\text { presente...) }\end{array}$ & $\begin{array}{c}\text { Ambivalente } \\
\text { produção industrial } \longleftrightarrow \\
\text { centralização }+ \\
\text { lógica capitalista } \\
\text { produção pós-industrial } \\
\text { (microeletrônica) } \ll \\
\text { descentralização }+ \\
\text { lógica não mercantil }\end{array}$ & $\begin{array}{c}\text { Sociedade } \\
\text { dual } \\
\text { "Sociedade da } \\
\text { multiatividade" } \\
\text { (Misérias do } \\
\text { presente...) }\end{array}$ \\
\hline $\begin{array}{l}\text { Década } \\
\text { de } 2000\end{array}$ & $\begin{array}{l}\text { Negativo } \\
\text { (historica- } \\
\text { mente } \\
\text { específico) }\end{array}$ & $\begin{array}{l}\text { Social } \\
\text { (trabalho } \\
\text { alienado) } \\
\text { Superável } \\
\text { (abolição do } \\
\text { trabalho) }\end{array}$ & $\begin{array}{l}\text { Impessoal } \\
\text { (superável) }\end{array}$ & Inexistência & Incondicional & $\begin{array}{c}\text { Positivo } \\
\text { “autoprodução high- } \\
\text {-tech" }< \\
\text { produtividades elevadas } \\
\text { + controlo/autogestáo } \\
\text { (“apropriável”) }\end{array}$ & $\begin{array}{c}\text { Sociedade } \\
\text { pós-mercantil } \\
\text { (abolição do tra- } \\
\text { balho, do valor, } \\
\text { da mercadoria } \\
\text { e do dinheiro) }\end{array}$ \\
\hline
\end{tabular}

Fonte: elaborado pelo autor. 
$\mathrm{Na}$ década de 1950, a principal influência de Gorz foi a obra $O$ ser e o nada, de Jean-Paul Sartre. Assim, nos seus dois primeiros livros - Fundamentos para uma moral (Gorz, [1955] 1977) e O traidor (Gorz, [1958] 1989b) - a temática da alienação é analisada sobretudo do ponto de vista individual daquilo que Sartre designou por "má-fé". A superação da má-fé exige uma profunda autoanálise por parte de cada indivíduo com recurso à "psicanálise existencial". O intuito será conseguir uma "conversão radical" que coloque o indivíduo no caminho da "autenticidade" e de uma conduta eticamente irrepreensível enquanto expressão máxima da sua liberdade. $\mathrm{O}$ conceito de trabalho náo desempenha um papel fulcral nesses dois primeiros livros de Gorz, embora esteja implícito um entendimento positivo do mesmo, assim como da classe operária.

A moral da história (Gorz, [1959] 1969) pode ser considerada a primeira obra marxista de Gorz, acompanhando de perto as teses desenvolvidas por Sartre em Crítica da razão dialética (escrita na mesma época). $\mathrm{O}$ trabalho é agora entendido explicitamente de modo ontológico e definido como a essência do ser humano. Gorz desloca a sua atenção para a alienação no plano social, isto é, para o trabalho alienado. A dominaçáo vigente na sociedade moderna é conceituada, em última instância, como uma dominação direta exercida pela classe capitalista sobre a classe operária. Por conseguinte, a abolição da alienação implica libertar o trabalho do jugo que lhe é imposto exteriormente pelo capital. Isso exige uma ação coletiva da classe explorada, o proletariado, que é entendido como um sujeito revolucionário apriorístico. A ação do proletariado consistirá na apropriação coletiva dos meios de produçấo, o que traduz uma concepção positiva da tecnologia tal como existe sob a sua forma capitalista; a ênfase é colocada somente na modificação da forma da sua propriedade jurídica. A visão de uma sociedade pós-capitalista que emerge deste quadro teórico é a de um socialismo de Estado, entendido como a pré-condição necessária para a "moralização da existência" dos indivíduos.

O pensamento gorziano da década de 1960 traduz o compromisso cada vez mais vincado do autor com o marxismo tradicional. Dessa maneira, são evidentes vários elementos já introduzidos em $A$ moral da história: o trabalho continua a ser entendido como uma constante antropológica e a dominação capitalista continua a ser percepcionada redutoramente como uma dominação de classe. A classe operária ainda é o sujeito coletivo responsável pela emancipaçáo da humanidade; contudo, Gorz passa a atribuir um papel determinante à denominada "nova classe operária", isto é, aos trabalhadores qualificados e com níveis de competências mais elevados. Na sua ótica, esse grupo representa a vanguarda do proletariado, uma vez que a autonomia que esses operários exercem no seu trabalho - ainda que limitada sob o capitalismo - conduzi-los-á a reivindicar um controle cada vez maior do processo produtivo que, em última instância, será incompatível com os ditames da sociedade capitalista.

Isso conduz-nos ao segundo conceito-chave gorziano da década de 1960: a autogestão. Influenciado por Cornelius Castoriadis e pelos grupos operaístas italianos, Gorz vê na autogestão, isto é, no controle operário da produção industrial, o meio privilegiado de combater a alienaçáo no trabalho e de subverter a hegemonia do capital. O socialismo ainda é definido, à semelhança de $A$ moral da história, como a apropriação coletiva dos meios de produção, mas o modelo estatista deve agora ser combinado com o estabelecimento de conselhos operários. Por outras palavras, a planificaçấo central deve ser conjugada com a autogestão. Nesse sentido, a sua visão de uma sociedade pós-capitalista assenta numa hibridizaçáo algo contraditória da teoria leninista com a teoria conselhista (na tradição de Pannekoek, Mattick etc.).

O início da década de 1970 não trouxe qualquer mudança ao entendimento ontológico do trabalho nem à afirmação do proletariado como demiurgo do socialismo. Todavia, o conceito de dominação capitalista começa a modificar-se, em resultado da alteraçáo da concepção gorziana de tecnologia. A tecnologia é agora a "matriz a priori" que determina a forma das relaçóes sociais capitalistas. Se, em Divisão do trabalho e modo de produção capitalista (Gorz, 1976a; 1976b; [1973] 1976c), a dominação ainda parece ser percepcionada de modo subjetivo - a técnica, a tecnologia e a ciência predominantes foram introduzidas conscientemente pela classe capitalista para assegurar a 
manutenção do seu domínio -, a partir de Ecologia e política (Gorz, [1975] 1980), a dominação é eminentemente impessoal e o resultado inevitável da "civilização industrial" - capitalismo e indústria são coextensivos, pelo que a produção industrial é inerentemente opressiva e alienante.

Esse pessimismo anti-industrial e anticientífico traduz a viragem ecológica no pensamento de Gorz, devido sobretudo à influência de Ivan Illich. ${ }^{10}$ A produção industrial em larga escala não é passível de ser apropriada coletivamente ou de ser autogerida. Assim, uma vez que é impossível aboli-la completamente sem regredir para condiçóes pré-modernas, a solução avançada por Gorz passa, por um lado, por limitá-la à produção de um conjunto reduzido de bens essenciais e por colocá-la sob a égide do Estado. Por outro lado, devem ser adotadas "ferramentas conviviais" (Illich), ou seja, tecnologias com um impacto ambiental reduzido e que possam ser operadas autonomamente ("autogeridas") por pequenos grupos. O gigantismo industrial deve, sempre que possível, ser substituído por uma produção microssocial ecologicamente sustentável. A visão de uma sociedade pós-capitalista corresponde assim a uma rede de pequenas comunidades que produzem localmente a maioria dos bens de que necessitam, complementada pela produção industrial regida pela planificação central.

A década de 1980 traz a primeira grande ruptura no pensamento de Gorz. A partir de Adeus ao proletariado (Gorz, 1982 [1980]), o trabalho passa a ser entendido de um modo negativo e como uma forma de atividade historicamente especifica. A alienação do trabalho já não é superável, pois o trabalho é inerentemente uma atividade heterônoma. Consequentemente, em vez de libertar o trabalho, Gorz propóe que a humanidade se liberte do trabalho.

Nesse sentido, Gorz faz uma crítica feroz do movimento operário clássico e da sua glorificação do trabalho, e abandona a noção do proletariado enquanto sujeito revolucionário. Historicamente, a classe operária interiorizou as categorias capitalistas e limitou-se a lutar pelo reconhecimento no seio das mesmas. Gorz coloca as suas esperanças de transformação social naquilo que designa por "não classe dos não trabalhadores" -, o conjunto heterogéneo dos indivíduos que rejeitam a racionalida- de econômica e os valores capitalistas, mormente o trabalho. Não obstante, no final da década de 1980, em Metamorfoses do trabalho, Gorz (1989a [1988]) romperá definitivamente com a noção de um sujeito apriorístico ou "sujeito objetivo". ${ }^{11}$

Ademais, a Terceira Revolução Industrial aquela da microeletrônica - provocou uma mudança de paradigma no capitalismo: doravante são necessárias quantidades cada vez menores de trabalho para produzir quantidades cada vez maiores de bens e serviços. Isso significa, na ótica de Gorz, a crise incontornável do capitalismo enquanto sociedade do trabalho. ${ }^{12} \mathrm{O}$ trabalho já não pode continuar, como no passado, a garantir a integraçáo social dos indivíduos. ${ }^{13}$

Para fazer face a esse estado de coisas, Gorz preconiza a criação de uma "sociedade dual", composta por duas esferas com lógicas distintas: i) uma esfera heterônoma macrossocial baseada na produção mercantil; ii) uma esfera autônoma microssocial baseada na produção não mercantil. $\mathrm{O}$ elemento-chave da sociedade dual é a implementação de uma "política do tempo" assente na redução generalizada das horas de trabalho "heterônomo" - que acompanhe os aumentos da produtividade - e na redistribuição equitativa do trabalho (heterônomo) remanescente por todos os indivíduos. Em suma, o aumento exponencial da produtividade deve permitir a contração contínua do tempo de trabalho individual dedicado à esfera heterônoma e uma expansão correspondente do tempo dedicado às atividades autônomas.

Todavia, na ótica (equivocada) de Gorz, o valor é agora produzido pelas máquinas, pelo que é preciso haver uma redistribuição dos "meios de pagamento". Desse modo, a política do tempo tem como corolário lógico a atribuiçẫo de um rendimento básico como contrapartida do trabalho efetuado na esfera heterônoma. $\mathrm{O}$ rendimento básico será financiado através do lançamento de um imposto sobre a produção (crescentemente) automatizada da esfera mercantil.

A dominação vigente sob o capitalismo é inequivocamente caraterizada como impessoal (e insuperável na esfera da heteronomia). Mas, quanto à origem dessa dominação, subsiste uma aporia central em Gorz. Por vezes, o autor é capaz de dis- 
cernir a origem da dominação impessoal capitalista na sua forma de organização social, nomeadamente na desvinculação e autonomização da economia e das categorias a ela associadas (valor, mercadoria, trabalho etc.). Contudo, em outras ocasióes - à semelhança do que sucedia em Ecologia e política-, Gorz faz da tecnologia, literalmente, uma espécie de Deus ex machina, à qual é possível reconduzir todos os malefícios do capitalismo.

Isso conduz-nos à concepção gorziana de tecnologia. A produção industrial da esfera heterônoma é caraterizada como irremediavelmente alienante, não sendo passível de um controle coletivo, pois a produção em larga escala só pode ser organizada "racionalmente" de modo capitalista, centralizado e burocrático. Todavia, a microeletrônica pode ser aplicada a uma tecnologia soft, em pequena escala, descentralizada e, portanto, passível de ser gerida autonomamente por pequenos grupos de indivíduos (vislumbra-se aqui uma reminiscência das "ferramentas conviviais" de Ecologia e politica). Abre-se assim a possibilidade de construção de um nicho de produção pós-industrial que não é regulado pela lógica mercantil.

A teoria gorziana da década de 1990 não sofre alteraçóes substanciais, como se denota no Quadro 2. Destaca-se, nesse período, maior pessimismo e reformismo do autor, na sequência do colapso dos países do socialismo real. O capitalismo parece ser inultrapassável, pelo que o socialismo é redefinido enquanto delimitação da esfera de atuação "legítima" da racionalidade econômica.

$\mathrm{Na}$ década de 2000, ocorre a segunda grande ruptura no pensamento de André Gorz em virtude da descoberta da Nova Crítica do Valor. ${ }^{14} \mathrm{O}$ entendimento negativo do trabalho já não se consubstancia em mera redução dos horários de trabalho, mas na abolição do trabalho tout court, isto é, na sua superação prática enquanto forma de atividade fetichista e historicamente específica. Isso significa que a abolição da alienação e da heteronomia passam a ser concebíveis.

Gorz adota igualmente a distinção basilar entre riqueza (material e imaterial) e valor económico. A crise do trabalho significa forçosamente a crise do valor, o que coloca em cheque a reprodução da economia capitalista. Nesse sentido, o rendimento básico já não pode ser financiado ad infinitum através dos impostos coletados pelo Estado, mas terá de ser encarado como uma medida de emergência de caráter transitório.

Gorz abandona definitivamente o conceito de sociedade dual, uma vez que não há nenhuma esfera pretensamente "autônoma" que escape à influência do valor. A sociedade capitalista tem de ser transcendida na sua totalidade. Isso significa que a dominação impessoal (anteriormente imputada à "esfera heterônoma") passa a ser superável.

No que diz respeito à tecnologia, a disseminação da microeletrônica - e, em particular, da informatização e da automação - torna possível o estabelecimento da denominada "autoprodução high-tech". Em outros termos, é possível implementar uma produção em pequena escala com produtividades extremamente elevadas que seja plenamente controlável e gerida autonomamente. Portanto, para o último Gorz, a produção industrial em larga escala parece ser tendencialmente substituível pela produção em rede pós-industrial. ${ }^{15}$

A sua visão de uma sociedade pós-capitalista é, pois, a de uma sociedade pós-mercantil em que o trabalho, o valor, a mercadoria e o dinheiro são completamente abolidos, o que se coaduna perfeitamente com a teoria da corrente contemporânea conhecida como Nova Crítica do Valor.

\section{Conclusão}

\section{[O] desenvolvimento e a radicalização politica de movimentos desta natureza [Maio de 68] não pode brotar apenas da espontaneidade das massas. [...] [A] classe operária [...] será vencida [...] se o poder direto que conquista momentaneamente não for apoiado pela ofensiva politica de um partido revolucionário imerso no movimento de massa (Gorz, [1969] 1975b, p. 29).}

Na década de 1960, "para André Gorz, [...] é ainda o proletariado o sujeito privilegiado da revolução, da organização de uma sociedade emancipada que vai fornecer um sentido à vida" (Botelho, 2009 , p. 215). Nesse sentido, Gorz elabora um conjunto de propostas "relativas à estratégia para uma política da classe operária" (Silva, 2002, p. 
85), no seguimento da sua "descoberta [sobretudo em $A$ moral da história] do proletariado como único agente capaz de incorporar um projeto moral voltado para a busca da liberdade, para a superação da alienação" (Idem, ibidem).

Como a satisfação das necessidades básicas das pessoas se tornou possível no quadro do capitalismo, segundo Gorz a estratégia política do proletariado deveria refletir esse fato: era importante definir novas necessidades, de natureza qualitativa, que não podiam ser satisfeitas pelo capitalismo (Idem, p. 86). Desse modo, o conceito de alienação - central na obra gorziana da década de 1950 - "volta a entrar em cena" (Idem, ibidem), pois apenas ele permite apreender criticamente a realidade capitalista e ancorar o desenvolvimento de novas necessidades, não alienadas. É de salientar ainda que "o conceito de alienação, concebido inicialmente para ser aplicado à atividade do trabalho, é ampliado para que seja possível abarcar outras esferas da sociedade" (Idem, ibidem), nomeadamente o consumo.

Pode-se concluir que, nos textos deste período,

[...] o trabalho aparece como uma categoria ontológica capaz de mediar toda relação social e de fornecer o fundamento para uma teoria da consciência de classe. [...] Na verdade, a crença no proletariado como o único sujeito da transformação social revolucionária e a convicção de que o socialismo não pode ser concebido como resultado automático de desenvolvimentos históricos são duas pressuposições fortemente interligadas aos escritos de Gorz desse período (Silva, 2002, p. 87).

Nesse contexto, "a fábrica é assumida como sendo o lugar privilegiado de onde a articulação de uma estratégia revolucionária deve começar" (Idem, p. 103). Seguindo a tradição conselhista, "a reivindicação pelo controle do processo de trabalho adquire uma crescente significância em relação às lutas em torno dos salários e das horas de trabalho" (Idem, p. 104). Não obstante, embora o autor estabeleça como principal objetivo "o poder autónomo dos trabalhadores", ao mesmo tempo, de maneira bem leninista, considera que "essa tarefa não pode ser cumprida sem um partido político revolucionário" (Idem, p. 116). O partido deve ser a síntese e a "tradução política" da estratégia da classe operária (Idem, ibidem).

$\mathrm{Na}$ ótica de Gorz, então, "o trabalho se subordina ao capital porque seus suportes estão determinados por este, isto é, porque o trabalhador é dominado e explorado pelo capital" (Botelho, 2009 , p. 213). Por conseguinte, "o trabalho é [...] ontologicamente determinado em sua autonomia, mas (até agora) historicamente incapaz de afirmá-la pelas condições que o subordinaram ao capital" (Idem, ibidem). Botelho conclui acertadamente que:

Há uma grave contradição, como em Marx, com a própria reflexão mais detalhada da relação entre capital e trabalho. [...] O trabalho não pode ser, com o risco da imprecisão total, [...] "a forma eterna do metabolismo entre o homem e a natureza” se ao mesmo tempo ele é formal e substancialmente determinado por uma estrutura alheia [isto é, pelo capital]. A subordinação total implica no esvaziamento pleno [do estatuto ontológico do trabalho], portanto, não pode haver nada interior, um sentido emancipatório, sufocado, querendo se libertar, de uma condição que tanto formal quanto substancialmente está ancorada em predicados históricos. A não ser, óbvio, por sortilégio metafísico. [...] Gorz esbarra nessa contradição, não a assume, não toma consciência dela, ainda. [...] [T] udo será reavaliado e criticado em suas obras posteriores [a partir da década de 1980] (Botelho, 2009, pp. 215-216, grifos no original).

Todavia, seria redutor enquadrar os seus escritos dessa época exclusivamente na teoria marxista tradicional. O próprio Botelho acaba por reconhecer que "André Gorz reflete, aprofunda e desenvolve as temáticas da época de modo por vezes tradicional, por vezes original" (Idem, p. 208). Pode, com efeito, falar-se de uma ambiguidade fundamental na teoria gorziana da década de 1960 . Como refere Geoghegan,

A sensação com que se fica ao ler estes textos dos anos 60 é a de que se trata de material novo 
aprisionado em velhas categorias. Embora rejeite o vanguardismo bolchevique, Gorz ainda evidencia a herança do vocabulário e dos conceitos marxistas-leninistas. A composição da classe operária pode ter mudado, mas ela ainda é o sujeito revolucionário [...]. A instituição do partido como o partido [leninista] (The institution of the party as the party) também revela esta ligação com o passado. Estas categorias já estão, contudo, a rebentar pelas costuras (bursting at the seams) (Geoghegan, [1988] 2008, pp. 162-163, grifo no original).

Desse modo, Gorz é capaz de afirmar, por exemplo, que

[...] o movimento operário [...] lutou contra efeitos do desenvolvimento capitalista, mas não elevou o nível da luta à exigência de um tipo diferente de desenvolvimento. Pôs em questão os efeitos do crescimento económico, a injusta distribuição dos frutos desse crescimento, mas raramente atacou a qualidade e a finalidade desse crescimento. [...] [A] contestação do movimento operário se manteve, na maior parte das vezes, como contestação interna e subalterna em relação ao sistema capitalista (Gorz, 1968, p. 23, grifo no original).

Assim, em última instância, o movimento operário contribuiu para um "reforço do sistema capitalista". A luta pelo aumento dos salários, por exemplo, consubstancia-se simplesmente numa redistribuiçáo do rendimento nacional "dentro da lógica capitalista" (Idem, p. 24, grifo no original). O autor acrescenta que sob o domínio do "produtivismo" é impossível que a quantidade se transforme em qualidade, ou seja, que o crescimento da "riqueza e do conforto individual" se converta numa "passagem do reino da necessidade ao reino da liberdade" (Idem, p. 18). Antes de tudo, é crucial saber "para que produzir, para que e como trabalhar, para que e como viver" (Idem, ibidem, grifos no original).

É impossível não vislumbrar nessas passagens de Gorz algumas ideias - ainda em estado embrionário, é certo - que nortearão o seu pensamento nas décadas seguintes e que conduziráo ao abandono do marxismo tradicional. A seguinte citaçáo que, obviamente, náo é representativa da posiçáo de Gorz nesse período - antecipa a tese central de Adeus ao proletariado:

A automação lançará em crise todas as sociedades capitalistas, destruirá os critérios quantitativos e de eficiência que lhes servem de fundamento, manifestará que a utilização racional das máquinas [...] segundo as exigências de rendibilidade máxima só se obterá ao preço da utilização irracional dos homens, do seu tempo, das suas faculdades, em detrimento das suas exigências humanas (Gorz, [1964] 1975a, p. 260).

Podemos concluir que, embora não se possa falar de continuidade, em virtude das insuficiências e das aporias de um quadro conceitual norteado, em muitos aspectos, por um "marxismo-leninismo" mais ou menos ortodoxo, ${ }^{16}$ é ainda assim possível identificar alguns pontos de contato entre a teoria gorziana dos anos de 1960 e aquela preconizada a partir de Adeus ao proletariado (Gorz, [1980] 1982), publicado em 1980.

\section{Notas}

1 Ao longo deste artigo, utilizaremos o termo "marxismo tradicional" na acepção em que foi cunhado por Moishe Postone (2003 [1993]). Na ótica de Postone, o marxismo tradicional inclui todas as teorias de inspiração marxista que entendem o capitalismo meramente na base da propriedade (jurídica) privada dos meios de produção por parte dos capitalistas e da respectiva exploraçáo "subjetiva" dos trabalhadores, mediante a apropriação da mais-valia que estes produzem. A dominação impessoal, "quasi-objetiva" (Idem) que caracteriza o capitalismo, corporizada em abstraçóes reais - mercadoria, valor, trabalho, dinheiro etc. - é escamoteada em benefício de uma noção trans-histórica de dominação direta. Assim, o "motor da história" é constituído pela "luta de classes", pela elevação do proletariado a "sujeito da história" responsável pela construção de uma sociedade assente em uma ontologia do trabalho. O marxismo tradicional postula uma crítica do capitalismo "do ponto de vista do trabalho", ao invés de uma "crítica do trabalho" 
(Idem). O trabalho e a produção - mercantil e industrial - moderna são assumidos implicitamente de um modo positivo; a grande crítica lançada ao capitalismo é que este entrava o desenvolvimento das forças produtivas. Estamos, pois, perante uma concepção tendencialmente produtivista de socialismo. Em suma, o marxismo tradicional consubstancia-se na crítica da distribuição injusta da mais-valia produzida e na oposição da "anarquia do mercado" a uma planificação central do (tempo de) trabalho social.

2 Ademais, deve ser realçado que - ao contrário da visão mais comum na literatura citada - é errado considerar que, após a publicação de Adeus ao proletariado, a teoria de Gorz não sofreu mais alteraçóes até a morte do autor. Desse modo, por exemplo, o conceito de "sociedade dual" - consubstanciado no binômio esfera da autonomia/esfera da heteronomia -, adotado durante a década de 1980 e em parte da década de 1990, cederá lugar ao conceito de "sociedade da multiatividade" em Misérias do presente, riqueza do possível (Gorz, [1997] 1999b). Posteriormente, Gorz abandonará definitivamente a noção de que é possível a existência de uma "esfera autônoma" imune à lógica mercantil; na década de 2000, portanto, Gorz considera que essa antinomia tem de ser superada praticamente. Consideremos ainda outro exemplo: o conceito de trabalho. A partir de Adeus ao proletariado, Gorz preconiza um entendimento negativo do trabalho enquanto atividade irremediavelmente alienada. Todavia, ao longo das décadas de 1980 e 1990, o autor propóe meramente a redução do tempo de trabalho "heterônomo", enquanto em $O$ imaterial (Gorz, 2005) e, sobretudo, em Ecologica (Gorz, [2008] 2010), Gorz defende a aboliçáo do trabalho enquanto forma de atividade historicamente específica. De modo análogo, a mercadoria, o valor e o dinheiro deixam de possuir uma esfera de incidência "legítima" à la Habermas, governada pela racionalidade econômica, e passam a ser criticados tout court, enquanto categorias fetichistas.

3 Gollain (2000, p. 63) afirma que, não obstante as rupturas que caracterizam o pensamento do autor, "a leitura existencialista do marxismo e a fenomenologia constituem sem dúvida a inspiração mais importante de toda a obra de André Gorz, [...] conferindo-lhe a sua unidade". Lodziak e Tatman (1997, p. 56), por seu turno, referem que "os escritos tardios de Gorz são uma continuaçáo e um desenvolvimento da sua obra inicial". Granter (2009, p. 114) partilha esta opinião: "o núcleo fundamental (the deeper level) da análise de Gorz permaneceu invulgarmente consistente ao longo dos 43 anos subsequentes à publicação de Estratégia".
A mudança foi sobretudo na "ênfase" dada a determinados aspectos, que foi o resultado da "transformaçáo das condiçôes políticas e sociais" subjacentes ao pensamento gorziano (Idem, ibidem).

4 Esta posição não era consensual no seio da Nova Esquerda. Muitos intelectuais - nomeadamente Sartre e Marcuse - começaram a contestar o potencial revolucionário do proletariado dos países capitalistas ocidentais e a depositar as suas esperanças nos movimentos "anti-imperialistas" e de libertação nacional do chamado Terceiro Mundo (Lodziak e Tatman, 1997, p. 37).

5 N. da R.: Todas as traduçóes de citaçóes foram realizadas pelo autor; algumas, porém, sofreram intervençóes na edição do artigo para a Língua Portuguesa no Brasil.

6 Segundo Levy (1998, p. 4), a Nova Esquerda pode ser "entendida, grosso modo, como a resposta radical teórica e prática à ascensão do capitalismo afluente, que rompia simultaneamente com as tradiçóes político-intelectuais do comunismo ortodoxo e da social-democracia”.

7 Lodziak e Tatman (1997, p. 36) também defendem que os escritos de Gorz tiveram uma grande influência nos "ativistas estudantis" da década de 1960.

8 Como nota Castel (2013, p. 44), nesse período, Gorz situa-se bastante próximo do operaísmo italiano e, em particular, de Bruno Trentin, "que fazem da libertação do trabalho e da libertação pelo trabalho o objetivo político prioritário e o meio necessário para a libertação do ser humano".

9 Seis anos mais tarde, Gorz (1974, p. 17) continuará a defender que o objetivo da ciência náo pode ser o reforço da especializaçáo, mas sim "o progresso geral e a difusão do conhecimento no interior da comunidade [...] no seu conjunto". Assim, "qualquer progresso no conhecimento, na tecnologia e no poder que produza um divórcio permanente entre os especialistas e os não especialistas deve ser considerado nocivo" (Idem, grifo no original).

10 De acordo com Jean-Pierre Dupuy (2013, p. 99), a influência de Illich sobre Gorz "foi bastante mais profunda e duradoura do que aquilo que autor de Ecologia e politica dá a entender". Essa asserção é facilmente desmentida pelas inúmeras referências diretas a Illich (incluindo diversas citaçóes) por parte de Gorz ( por exemplo, Gorz, [1975] 1980, pp. 16 ss.). Aliás, Gorz foi um dos principais responsáveis pela divulgação da obra illichiana no mundo francófono.

11 Como seria de esperar, a crítica do trabalho, da visão messiânica do proletariado e da luta de classes valeram a Gorz inúmeras censuras oriundas do marxismo 
tradicional (Bowring, 1996, 2005; Levy, 1998, pp. 354-385; e Lodziak e Tatman, 1997, pp. 93-116, para uma análise detalhada das críticas feitas pelos marxistas tradicionais a Gorz). Assim, por exemplo, Antonio Negri, o teórico da "multidão", critica Gorz por este negar o caráter imediatamente revolucionário do sujeito trabalhador (Negri e Vincent, 1992). Note-se que a multidão negriana é um claro decalque do proletariado lukacsiano: é um sujeito "materialmente dado" (Idem), ou seja, um sujeito revolucionário em si- pelo que, paradoxalmente, é um sujeito objetivo - que apenas tem de adquirir consciência desse fato para si, algo dependente "unicamente" do "militantismo" (Idem). Não deixa de ser curioso que o Negri do final do século XX partilhe, no essencial, a mesma visão do Gorz dos anos de 1960 a esse respeito. Segundo Gorz palavras que também podem ser lidas como uma autocrítica às suas posiçóes pretéritas -, encontramos em Negri uma espécie de "imediatismo revolucionário" tomado de empréstimo aos "autonomistas" da década de 1970. Dá a impressão que "com a 'intelectualidade de massa' um sujeito anticapitalista se autoconstitui no seio da atividade produtiva e que este sujeito 'materialmente dado' se coloca de imediato 'como alternativa à força produtiva do capital'" (Gorz, 2002, p. 83). Em outros termos, o trabalhador "imaterial" pós-fordista escaparia incólume à socializaçáo negativa do capital e constituiria imediatamente, através da sua prática, uma sociabilidade alternativa pós-capitalista (Kurz, 2007, secção 13, para uma crítica impiedosa do pós-operaísmo negriano).

12 No final da década de 1980, Anthony Giddens criticava essa tese de Gorz. Giddens (1987, p. 289) defendia que, "apesar de atualmente as taxas de crescimento económico serem modestas ou até por vezes negativas, e de se assistir a uma contração do Estado do Bem-Estar em muitos países e a um desemprego em larga escala, náo se deve concluir precipitadamente que estas são agora necessariamente as condiçóes genéricas das sociedades industrializadas em bloco". Em particular, a associação do desemprego à produçáo automatizada não passa de uma "especulação vaga" (Idem, p. 291). Parece-me, contudo, que as últimas décadas confirmaram inequivocamente a crise da "sociedade do trabalho" identificada por Gorz. É especialmente notório que a crise econômica e financeira de 2007 ainda não tenha sido debelada e que a mesma tenha atingido fortemente países do centro capitalista, com um aumento brutal do desemprego. Ademais, vários autores têm defendido teses similares às de Gorz (Brynjolfsson e McAfee, 2014; De Masi, 2000; Frey e Osborne,
2013; Kurz, [1991] 1999, 2014; Rifkin, 1995).

13 Segundo Robert Castel (2013, pp. 43-44), "defender um 'êxodo da sociedade do trabalho" é "ao mesmo tempo errado sociologicamente e perigoso politicamente". Castel censura em Gorz "o abandono completo da exigência de continuar a fazer do trabalho um elemento de integração [social]" (Idem, p. 47), pois "foi o trabalho-emprego que conferiu ao assalariado um estatuto que é igualmente um reconhecimento social e jurídico. Pode-se dizer que ele dignifica o trabalhador" (Idem, p. 51). Parece-me que o diagnóstico de Gorz é acertado e que as críticas de Castel são infundadas. O trabalho está a tornar-se progressivamente um mecanismo de exclusão social para milhóes de pessoas (Grupo Krisis, [1999] 2003; Kurz, 1995, 2004). Portanto, não é Gorz que nega esse estatuto ao trabalho, mas sim o próprio funcionamento quotidiano da economia capitalista. Para além disso, é inteiramente discutível que o trabalho "dignifique" o ser humano.

14 Será publicado em breve um artigo onde discutimos a relação entre o Gorz tardio e a Nova Crítica do Valor. Essa corrente de pensamento surge em finais da década de 1970/meados da década de 1980 e tem raízes na Escola de Frankfurt e na crítica da economia política de Marx, nomeadamente nas suas teorias do fetichismo e da crise. Os seus principais representantes são Robert Kurz, Moishe Postone e Jean-Marie Vincent (Jappe, 2006).

15 No entanto, convém não esquecer que "o fabrico dos componentes eletrónicos associado à 'tecnologia da informação' defendida por Gorz" também é parcialmente poluente e, consequentemente, não se enquadra "facilmente no ethos da ecologia política" (Little, [1996] 2013, p. 68) gorziana. Com efeito, "muitos dos processos envolvidos no fabrico da tecnologia informática são na verdade bastante poluentes (dirty) quimicamente" (Martell apud Little, idem, pp. 68-69).

16 O marxismo-leninismo é evidente nas noçốes de que o Estado deve converter-se no "senhor dos centros realmente motores da economia" (Gorz, 1968, p. 163), de que o poder da classe operária reside na possibilidade de submeter as suas condiçóes de trabalho ao seu poder coletivo (Idem, p. 146) e de que "a URSS não é somente uma grande nação; é a primeira potência socialista" (Idem, p. 204). Esses exemplos poderiam ser facilmente multiplicados. 


\section{BIBLIOGRAFIA}

ABRAMOVAY, Ricardo. (2009), "Anticapitalismo e inserção social dos mercados". Tempo Social, 21 (1): 65-87.

BOROT, Luc. (2001), “André Gorz, l'utopisme realiste et le syndicalisme intégral". Cités, 8: $35-49$.

BOTELHO, Maurilio Lima. (2009), Crise da sociedade do trabalho: teorias em conflito. Tese de doutorado. Instituto de Ciências Humanas e Sociais, UFRRJ.

BOWRING, Finn. (1996), "Misreading Gorz". New Left Review, I (217): 102-122.

. (2000), André Gorz and the Sartrean legacy: arguments for a person-centred social theory. Londres/Nova York, Macmillan/St. Martin's Press.

. (2005), "André Gorz: autonomy and equity in the post-industrial age". The Sociological Review, 53 (s1): 134-147.

BROOKS, Christopher D. (2010), Exile: an intellectual portrait of André Gorz. Tese de doutorado. University of California.

BRYNJOLFSSON, Erik \& McAFEE, Andrew. (2014), The second machine age: work, progress, and prosperity in a time of brilliant technologies. Nova York, W.W. Norton \& Company.

CAMARGO, Sílvio. (2010), "Experiência social e crítica em André Gorz e Axel Honneth". RBCS - Revista Brasileira de Ciências Sociais, 25 (74): 107-120.

CARDOSO, Luís Antônio. (2011), "A categoria trabalho no capitalismo contemporâneo". Tempo Social, 23 (2): 265-595.

CASTEL, Robert. (2013), "André Gorz et le travail: une interprétation critique", in A. Caillé e C. Fourel (orgs.), Sortir du capitalisme: le scénario Gorz, Paris, Le Bord de L'eau.

DE MASI, Domenico. (2000), O futuro do trabalho: fadiga e ócio na sociedade pós-industrial. 5. ed. Rio de Janeiro/Brasília, José Olympio Editora/Editora da UnB.

DUPUY, Jean-Pierre. (2013), "Gorz et Illich”, in A. Caillé e C. Fourel (orgs.), Sortir du capitalisme: le scénario Gorz, Paris, Le Bord de L'eau.
FREITAS, Revalino Antônio de. (2008), “Tempo de trabalho e autonomia: uma homenagem a André Gorz". Sociedade e Cultura, 11 (1): 131-138.

FREY, Carl Benedikt \& OSBORNE, Michael A. (2013), "The future of employment: how susceptible are jobs to computerisation?”. Disponível em: <http://www.oxfordmartin.ox.ac.uk/ downloads/academic/The_Future_of_Employment.pdf $>$. Acesso em: 10 jun. 2014.

GEOGHEGAN, Vincent. ([1988] 2008), Utopianism and Marxism. 2. ed., Berna, Peter Lang.

GIDDENS, Anthony. (1987), Social theory and modern sociology. Stanford, Stanford University Press.

GOLLAIN, Françoise. (2000), Une critique du travail: entre écologie et socialisme. Paris, La Découverte.

GOMES, Marcelo. (2005), Processo de trabalho no século XX e pensamento social: uma crítica à fundamentação teórica e empírica da "superação" da alienação em Adeus ao proletariado de André Gorz. Dissertação de mestrado, São Paulo, Unesp.

GORZ, André. (1968), O socialismo difícil. Rio de Janeiro, Zahar Editores. [Título original: Le socialisme difficile]. ([1959] 1969), Historia y enajenación. México, Fondo de Cultura Económica. [Título original: La morale de l'histoire].

(1974), "Sobre el carácter de clase de la ciencia e de los científicos". Les Temps Modernes, 330. Disponível em: <http://www.omegalfa.es/downloadfile.php?file=libros/sobre-el-caracter-de-clase-de-la-ciencia-y-los-cientificos. pdf>. Acesso em: 24 nov. 2013.

. ([1964] 1975a), "Estratégia operária e neocapitalismo", in , Reforma e revolução, Lisboa, Edições 70. [Título original: Stratégie ouvrière et néocapitalisme.]

([1969] 1975b), "Prefácio", in

Reforma e revolução, Lisboa, Ediçôes 70. [Título original: Réforme et révolution.]

. ([1966] 1975c), "Reforma e revolução", in __ Reforma e revolução, Lisboa, Ediçôes 70. [Título original: Réforme et révolution.] . ([1973] 1976a), "Prefácio", in A. Gorz et al., Divisáo social do trabalho e modo de produ- 
ção capitalista, Porto, Escorpião. [Título original: Critique de la division du travail.]

. ([1973] 1976b), "O despotismo de fábrica e o seu futuro", in A. Gorz et al., Divisáo social do trabalho e modo de produção capitalista, Porto, Escorpião. [Título original: Critique de la division du travail.]

. ([1973] 1976c), "Técnica, técnicos e luta de classes”, in A. Gorz et al., Divisão social do trabalho e modo de produção capitalista, Porto, Escorpião. [Título original: Critique de la division du travail.]

([1955] 1977), Fondements pour une morale. Paris, Galilée.

([1975] 1980), Ecology as politics. Montreal, Black Rose Books. [Título original: Écologie et politique.]

. ([1980] 1982), Farewell to the working class: an essay on post-industrial socialism. Londres/Sidney, Pluto Press. [Título original: Adieux au prolétariat.]

. ([1988] 1989a), Critique of economic reason. Londres/Nova York, Verso. [Título original: Métamorphoses du travail.]

. ([1958] 1989b), The traitor. Londres/ Nova York, Verso. [Título original: Le traître.] ([1993] 1997), "A dialogue with Gorz", in C. Lodziak e J. Tatman, André Gorz - A critical introduction, Londres/Chicago, Pluto Press.

. (1999a), "Oficios del saber y del trabajo". Entrevista a André Gorz por Michel Klotowsky. Disponível em: <http://www.verds-alternativaverda.org/upload/AGorz\%20entrevistes. pdf>, pp. 1-7. Acesso em: 10 set. 2013.

. (1999b [1997]), Reclaiming work: beyond the wage-based society. Cambridge, Polity Press. [Título original: Misères du présent, richesse $d u$ possible.]

. (2002), "Ecologie et socialisme". Ecologie et Politique, 24: 71-95.

. (2005), O imaterial: conhecimento, valor e capital. São Paulo, Annablume. [Título original: L'immatériel: connaissances, valeur et capital.]

([2008] 2010), Ecologica. Londres/Nova York/Calcutá, Seagull Books. [Título original: Ecologica.]
GRANTER, Edward. (2009), Critical social theory and the end of work. Farnham e Burlington, Ashgate.

GRUPO KRISIS. ([1999] 2003), Manifesto contra o trabalho. Lisboa, Antígona.

HIRSH, Arthur. (1981), The French New Left: an intellectual history from Sartre to Gorz. Boston, South End Press.

JAPPE, Anselm. (2006), As aventuras da mercadoria. Para uma nova critica do valor. Lisboa, Antígona. . (2008), Guy Debord. Lisboa, Antígona.

KURZ, Robert. (1995), "O pós-marxismo e o fetiche do trabalho. Sobre a contradição histórica na teoria de Marx". Disponível em: < http:// obeco.planetaclix.pt/rkurz136.htm>. Acesso em: 20 jan. 2015.

. ([1991] 1999), O colapso da modernização. Da derrocada do socialismo de caserna à crise da economia mundial. 5. ed., Sáo Paulo, Paz e Terra. . (2004), "A substância do capital: o trabalho abstracto como metafísica real social e o limite interno absoluto da valorização. Primeira Parte: A qualidade histórico-social negativa da abstracção trabalho". Disponível em: <http:// obeco.planetaclix.pt/rkurz203.htm>. Acesso em: 13 maio 2014).

. (2007), "Cinzenta é a árvore dourada da vida e verde é a teoria. O problema da práxis como evergreen de uma crítica truncada do capitalismo e a história das esquerdas". Disponível em: <http://obeco.planetaclix.pt/rkurz288. $\mathrm{htm}>$. Acesso em: 13 maio 2014).

(2014), Dinheiro sem valor: linhas gerais para uma transformação da crítica da economia politica. Lisboa, Antígona.

LANE, Jeremy F. (2011), "Disaffection in the post-fordist workplace: figurations of "immaterial labour' in recent French theory and literature". Modern \& Contemporary France, 19 (4): 495509.

LANGER, André. (2003), "Pelo êxodo da sociedade salarial - a evolução do conceito de trabalho em André Gorz". Cadernos IHU, 5. Disponível em: <http://www.ihu.unisinos.br/images/stories/cadernos/ihu/005cadernosihu.pdf $>$. Acesso em: 2 mar. 2014. 
LEVY, Andrea Terry. (1998), Reframing socialism from the fifties to the fin-de-siecle: the intellectual odyssey of André Gorz. Tese de doutorado, Concordia University.

LITTLE, Adrian. ([1996] 2013), The political thought of André Gorz. 2. ed. Nova York, Routledge.

LODZIAK, Conrad \& TATMAN, Jeremy. (1997), André Gorz: a critical introduction. Londres/ Chicago, Pluto Press.

MALLET, Serge. ([1963] 1975), The new working class. Nottingham, Spokesman Books.

MELLO, Gustavo Moura de. (2007), Algumas respostas teóricas para as vicissitudes do capitalismo contemporâneo: crítica ou fetichismo? Dissertação de mestrado, São Paulo, USP.

MIGUEL, Luis Felipe. (2006), "Utopias do pós-socialismo: esboços e projetos de reorganizaçáo radical da sociedade". RBCS - Revista Brasileira de Ciências Sociais, 21 (61): 91-114.

NEGRI, Antonio \& VINCENT, Jean-Marie. (1992), "Paradoxes autour du travail". Futur Antérieur, 2. Disponível em: <http://www. multitudes.net/Paradoxes-autour-du-travail $>$. Acesso em: 26 ago. 2015.

POSTER, Mark. (1975), Existential Marxism in postwar France: from Sartre to Althusser. Princeton, Princeton University Press.

POSTONE, Moishe (2003 [1993]), Time, labor, and social domination: a reinterpretation of Marx's critical theory. 2. ed. Nova York/Cambridge, Cambridge University Press.

QUEIROZ, José Benevides. (1999), As aporias do pensamento de André Gorz nos anos 50 e 60 . Dissertação de mestrado, Campinas, IFCH-Unicamp.

RIFKIN, Jeremy. (1995), The end of work: the decline of the global labor force and the dawn of the post-market era. Nova York, Tarcher/Putnam.

RODRIGUES, Iram Jácome. (2009), "Estratégia operária e neocapitalismo". Tempo Social, 21 (1): 51-64.

SILVA, Josué Pereira da. (2002), André Gorz: trabatho e política. São Paulo, Annablume.

SOBEL, Richard (2010). "La philosophie du travail de Gorz est-elle marxienne?”. Comunicação apresentada no seminário Hétéredoxies du CES-Matisse, 13 de abril. Disponível em: $<$ http://ces.univ-paris1.fr/membre/seminaire/ heterodoxies/Pdf/SobelPhiloLGorzAvril10. pdf>. Acesso em: 2 mar. 2014.

. (2011), "La règne de la nécessité" borne-t-il l'émancipation sociale? Deux lectures croisées de l'utopie communiste chez Marx". Revue Économique, 62 (2): 187-214. 


\section{TRÊS VIVAS AO PROLETARIADO! PARA UMA CONTEXTUALIZAÇÁO DA OBRA GORZIANA DA DÉCADA DE 1960}

Nuno Miguel Cardoso Machado

Palavras-chave: André Gorz; Marxismo; Nova Esquerda; Trabalho; Proletariado.

André Gorz é conhecido sobretudo como um dos principais intervenientes no debate sociológico contemporâneo acerca da crise da sociedade do trabalho. Em Adeus ao proletariado, publicado em 1980, o autor critica ferozmente o marxismo tradicional e a sua "religião do proletariado". Todavia, a vasta obra que Gorz publicou nas décadas anteriores não tem merecido a devida atenção. $\mathrm{O}$ intuito deste artigo é analisar detalhadamente o pensamento gorziano da década de 1960 e demonstrar que, nesses textos, Gorz defende, em muitos aspectos, teses diametralmente opostas àquelas sustentadas a partir de Adeus ao proletariado.

\section{THREE CHEERS FOR THE WORKING CLASS! NOTES ON THE GORZIAN WORK OF THE 1960'S}

Nuno Miguel Cardoso Machado

Keywords: André Gorz; Marxism; New Left; Labor; Proletariat

André Gorz is known as one of the main authors in the contemporary debate on the crisis of the labor-based society. In Farewell to the working class, published in 1980, he fiercely criticizes traditional Marxism and its "religion of the proletariat". However, Gorz's earlier work, published in previous decades, has not been given proper attention. The aim of this article is to analyze in detail his thought of the 1960's, showing that in those writings Gorz sustains theses that, in many aspects, are diametrically opposed to the ones upheld from Farewell to the working class onwards.
VIVE LE PROLÉTARIAT! NOTES

SUR L'GUVRE GORZIENNE

DANS LES ANNÉES 1960

Nuno Miguel Cardoso Machado

Mots-clés: André Gorz; Marxisme; Nouvelle Gauche; Travail; Prolétariat.

André Gorz est connu surtout comme un des principaux intervenants dans le débat sociologique contemporain à propos de la crise de la société du travail. Dans Adieux au prolétariat, publié en 1980, Gorz critique férocement le marxisme traditionnel et sa «religion du prolétariat». Cependant, l'œuvre vaste publiée par Gorz au cours des décennies antérieures n'avait pas été étudiée avec l'attention qui lui était due. L'objectif de cet article est de fournir une analyse détaillée de la pensée gorzienne des années 1960 et de démontrer que, dans ses écrits, Gorz défend, sur plusieurs aspects, des thèses diamétralement opposées à celles soutenues à partir d'Adieux au prolétariat. 